
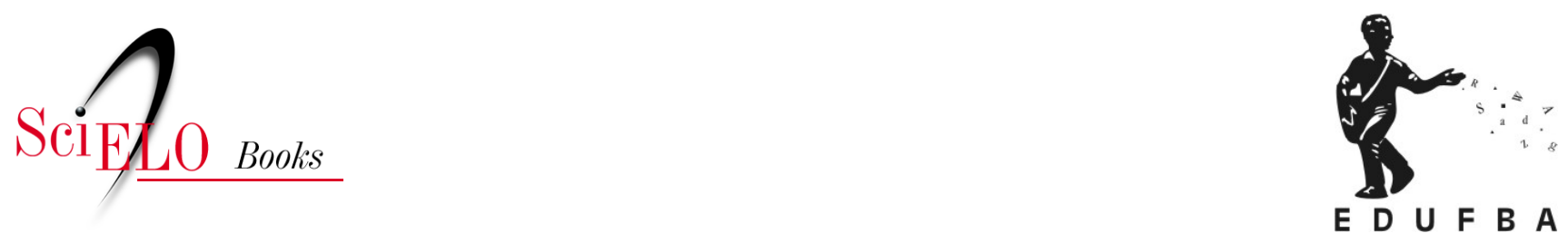

\title{
O realismo como desafio
}

\author{
Eduardo Tudella
}

\section{SciELO Books / SciELO Livros / SciELO Libros}

TUDELLA, E. O realismo como desafio. In: A luz na gênese do espetáculo [online]. Salvador: EDUFBA, 2017, pp. 373-410. ISBN: 978-85-232-1858-4.

https://doi.org/10.7476/9788523218584.0013.

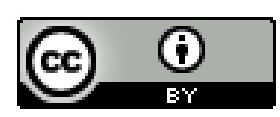

All the contents of this work, except where otherwise noted, is licensed under a Creative Commons Attribution $\underline{4.0 \text { International license. }}$

Todo o conteúdo deste trabalho, exceto quando houver ressalva, é publicado sob a licença Creative Commons Atribição 4.0.

Todo el contenido de esta obra, excepto donde se indique lo contrario, está bajo licencia de la licencia Creative Commons Reconocimento 4.0. 


\section{O REALISMO COMO DESAFIO}

Ao se referiràs manifestações teatrais reconhecidas como realistas na segunda metade do século XIX, o historiador Oscar Gross Brockett (1995, p. 383, tradução nossa) acentua uma abordagem referendada por muitos outros: "[...] montagens que procuravam representar ações observadas cientificamente, em espaços físicos que demonstravam a interdependência entre personagem e ambiente [...]". ${ }^{1}$ Considerando tal assertiva é possível ponderar que a aplicação da luz em um espetáculo realista deveria representar alto grau de dificuldade técnica, uma vez que envolvia a abordagem científica das relações entre o ser humano e seu espaço. Do artista que desejasse alcançar com a luz a artificialização capaz de levar o espectador a acreditar na realidade da cena seria exigida grande familiaridade com a convenção realista, que deveria implicar no domínio dos aspectos científicos do problema. Ainda assim, a luz para o realismo é, por vezes, interpretada de modo generalizado e superficial, resultando em

\footnotetext{
1 "[...] productions that sought to represent scientifically observed actions in physical
} spaces which demonstrated the interdependence of character and environment [...]." 
opiniões que parecem emergir de uma intuição inconsequente que podem gerar distorções quando se põe em jogo a exegese teórica desse teatro "realista".

Buscando um "retrato" da realidade cotidiana a proposição do realismo dela se afasta, uma vez que depende de certa artificialidade (aquela artificialidade inerente a uma convenção artística) para criar a ilusão. Ao falar em cena, um ator tanto pode aplicar técnicas reconhecidas que lhe permitam alcançar o público com sua elocução, seus gestos, movimentos e emoções, quanto pode perseguir o cumprimento do mesmo objetivo através de soluções encontradas ao acaso. De todo modo, ambos os processos se referem a uma flagrante busca da artificialização imprescindível para construir a cena "realista".

Um cenógrafo que se interessava pelo realismo podia aplicar a perspectiva para convencer o olhar do espectador de uma profundidade com a qual o palco efetivamente não contava. Como se pode ver, o teatro realista defendia sua convenção criando uma ilusão de real, com o "falso". Um falso positivamente justificado - no caso - pela necessidade de gerar verossimilhança, ilusão de realidade.

Se o dramaturgo desejava criar uma fiel representação da realidade, ele já tomava - ou deveria ter tomado - uma série de decisões no que se refere ao ambiente onde a ação ocorria, para promover relações com a verossimilhança. A escolha recaía, em muitos casos, sobre acontecimentos do cotidiano, cujos lugares permitissem sua elaboração cenográfica num palco que atendesse ao modelo da tradição "italiana", observando questões de visibilidade e acústica, por exemplo, os comentários de André Antoine (1858-1943), que serão abordados ainda no capítulo em curso. O público deveria estar acomodado numa relação frontal com o palco, usufruindo de visão total do espaço da ação, que deveria estar alocada no interior da caixa cênica. Respeitado o limite da quarta parede, o espectador encontrava-se diante de uma espécie de "espelho" virtual da realidade, transparente para evitar a reflexão objetiva da plateia. O que se queria ver na cena era a projeção dos desejos do espectador mixados aos desejos das personagens, revelados em eventos e lugares do cotidiano.

Pensava-se que o drama instalado em ambientes fechados e envolvendo acontecimentos de natureza cotidiana, realizados dentro dos princípios da ilusão, permitiria ao espectador acreditar que, diante dele, encontrava-se efetivamente um recorte da "realidade" transplantado para a cena. A convenção alcançava, portanto, alto grau de sofisticação, quando solicitava que o público aceitasse como única interferência dos artistas do teatro realista a anulação de uma das paredes do ambiente - a "quarta" parede, vista em Diderot. Isso redundaria na exposição pura e simples de acontecimentos que ocorriam como se o espectador testemunhasse cenas do dia a dia das personagens. E o teatro precisava 
contar com a parceria do espectador que, comparecendo em data e hora marcadas, concordaria em permanecer acomodado em uma poltrona por determinado período. Ele também aceitava as convenções da fala, do gesto e do movimento tecnicamente (artificialmente) elaborados para firmar a ilusão de realidade numa configuração teatral de ação, tempo e espaço.

Isso não significa, necessariamente, que a dramaturgia realista excluiu ambientes externos e de grande amplitude. Ao contrário, há exemplos de peças cuja ação se passa em lugares que representavam grande desafio para essa estética de interiores. De todo modo, a práxis cênica realista afastava-se da realidade cotidiana à medida que aplicava métodos sofisticados de artificialização, apresentando radicais "simulacros" do real. E para que tais objetivos fossem alcançados numa manifestação de natureza visual contundente, a luz deveria assumir amplas responsabilidades. Do ponto de vista técnico, na base do combate ao realismo havia mais do que uma guerra contra a imitação da natureza. Na disputa também estavam em jogo os procedimentos de artificialização que criavam a ilusão.

O ator realista expressava desejos revelando objetivos da personagem, a quem conferia credibilidade através de excelência técnica, capaz de resistir à avaliação da crítica e do público. A criação do espaço da cena, por sua vez, exigia um tratamento visual particular, já que todo ambiente reage integral e dinamicamente à luz, mesmo que se trate de um ambiente fechado, uma pequena e simples sala de estar em qualquer classe social, localização geográfica, estação do ano, momento do dia - ou da noite. No mesmo contexto, um ambiente ao ar livre, quando relacionado a qualquer uma das variáveis mencionadas, desenvolvia reações objetivas, físico-químicas, geométricas, tridimensionais, com a luz. Isso transforma a alegada reprodução "fotográfica" de um ambiente em um problema cênico-visual com particularidades que exigiam grande domínio técnico. E a quarta-parede ocupava um lugar importante no contexto.

Sendo uma parede "falsa, imaginária e inexistente" na cena, ela deixava uma lacuna física importante e estabelecia uma grave ausência para a interação da luz com o ambiente a ser representado, já que no lugar dessa "quarta" parede faltava efetivamente um corpo, um anteparo ou obstáculo material para que tal interação se completasse, objetivamente. Daí, o resultado visual na cena deveria ser artificialmente criado, configurando-se uma "não verdade", uma resposta técnica que fisicalizaria a convenção. Tome-se como exemplo o "espaço" mencionado a seguir: cômodo único numa noite sem luar, inverno (janela e porta opacas, fechadas para evitar o incômodo causado pelas baixas temperaturas), com uma simples lâmpada incandescente pendurada no centro do ambiente, a dois metros e 
cinquenta centímetros do piso. Ao construir tal ambiente no teatro, sob a convenção da quarta-parede, o iluminador não contava com as condições do lugar real que teria provocado o dramaturgo e, mais tarde, o cenógrafo. Ele encarava, então, um problema-chave: convencer o público da "realidade" da luz criada para a cena; ou seja, para atender à convenção, o iluminador precisava construir com a luz um corpo inexistente fazendo crer que havia uma, ou mais paredes, no "lugar" da falsa quarta-parede (Figura 77).

A solução poderia envolver procedimentos e terminologia particulares, como as variáveis de luminância e iluminância. ${ }^{2}$ Termos como esses deveriam, no entanto, integrar o vocabulário de quem precisava criar luz para a cena realista. Simplificando, em uma cena de tal natureza, o designer deveria "pré-ver" e calcular o iluminamento produzido pela fonte em questão (no caso da cena, uma simples lâmpada que pende do teto). Ele deveria considerar também a luminância produzida na sua dinâmica relação com os obstáculos. Isso poderia incluir não apenas a quarta-parede, mas superfícies diversas como o piso, outras paredes, móveis, objetos e até seres vivos. Incidindo sobre eles a luz retornaria para o ambiente, modificada pelo processo, emprestando qualidade visual aos volumes, interagindo com suas formas, texturas e cores.

As bases científicas do tratamento realista poderiam, num determinado sentido, limitar "criatividades" exacerbadas e, portanto, criar resultados menos "artísticos", se comparados às mudanças mecanicamente feéricas, de uso regular, hoje em dia. No que se refere ao propósito da presente abordagem, contudo, reitere-se a intenção de compreender, tanto no realismo quanto em qualquer outra abordagem da cena, modos específicos de construção visual, aplicados para revelar, discutir, e/ou provocar no público a apreensão do ambiente concebido para sua realização.

Por um lado, a elaboração realista da luz de um espetáculo poderia ser encarada como vantagem ou facilidade, uma vez que o artista teria modelos para estabelecer analogias diretas com o cotidiano. Por outro, certas circunstâncias poderiam representar graves limitações para o alcance desses resultados: desde tempo reduzido, orçamento insuficiente para a aquisição ou locação de instrumentos, acessórios e sistemas de controle, e até condições inapropriadas de casas de espetáculo, se elas fossem projetadas, construídas e/ou equipadas por profissionais

\footnotetext{
2 A luminância pode ser definida como a intensidade luminosa que emana [reflete] de uma superfície sobre a qual incidiu um fluxo luminoso. A luminância atua em direta relação com a iluminância, ou o fluxo luminoso irradiado por uma fonte [lâmpada], cuja relacão com a superfície sobre a qual incide define uma grandeza luminotécnica, também conhecida como iluminamento ou nível de iluminação.
} 
sem qualificação para conceber e projetar um teatro, inclusive no que se refere a aspectos específicos da luz. Além disso, o iluminador que aceitasse compreensões equivocadas do realismo poderia afundar seu trabalho na banalidade da indefinição.

Se um espetáculo procurasse recuperar, atualmente, a estética realista, um dos principais aspectos favoráveis a essa recuperação se apoiaria na precisão possibilitada pelos instrumentos, acessórios e sistemas de controle hoje disponíveis, aliada à flexibilidade de uma casa de espetáculos qualificada para ser reconhecida como um teatro. Vale lembrar que não é difícil encontrar um espaço que recebeu tal denominação, mesmo sem apresentar condições técnicas para abrigar um espetáculo. E ainda, para efetivar a abordagem realista, a equipe precisaria contar com artistas treinados. Tais variáveis resultariam em enormes diferenças e dificuldades, se comparássemos, como exemplo, com aquilo que André Antoine encontrava no seu teatro, naquela fase inicial de aplicação da luz elétrica às montagens. As diferenças de natureza tecnológica entre o que está hoje disponível e o que ele encontrava àquele momento nos levam a imaginar as dificuldades, assim como os resultados que se poderia alcançar, na segunda metade do século XIX.

\section{REALISMO, LUZ E CRÍTICA}

Essa conjectura sugere a aproximação do pesquisador com aquilo que geralmente se compreende como realismo na luz teatral daquele período, e que, na compreensão de Jean-Jacques Roubine (1982b, p. 22), é assim apresentado: “[...] uma definição atmosférica do espaço. [...] um nevoeiro do crepúsculo ou um luar sentimental". Ele estava comparando o realismo em uso na luz teatral do final do século XIX ao tratamento que apareceu no trabalho de Loie Fuller (1862-1928), quando ela começou a desenvolver o que ficou conhecido como Dança da saia (Skirt dance), originando a performance denominada Serpentina [Serpentine (1891)]. (Figura 105) O grafismo, a abordagem do corpo como forma abstrata em parceria com o uso da cor, estranhos à proposição realista, lhe renderam notoriedade. Seu trabalho será comentado na abordagem da práxis cênica aqui denominada "não realista", levando-se em conta diversas reações ao "realismo" ocorridas no século XIX.

Roubine pensa que Loie Fuller teria transformado a luz num parceiro autêntico ao incorporar cor e fluidez, indo além da "definição atmosférica" realista ao efetivar interferências no corpo do performer. Isso pode sugerir que para aceitar ou considerar a presença (ou a atuação) da luz, tanto a teoria, quanto a crítica e 
o público parecem entrar em acordo: essa presença somente se efetiva em "efeitos", na "exibição". Fica a impressão que se quer ver, sempre, truques de prestidigitação. O termo "parceiro", no entanto, parecerá aplicado com parcialidade às ligações entre a luz elétrica e às iniciativas não realistas se intentar sugerir que somente essas iniciativas incorporaram a luz como parceira. Ao contrário disso, talvez seja possível ponderar que a cena realista somente se poderia efetivar se tivesse a luz como parceira. Ou seja, para realizar a mencionada "definição atmosférica", o iluminador envolvido em uma montagem realista precisava conceder à luz o status de parceira do discurso visual que sustentava o realismo. Pode não ser fácil de compreender. Ressalte-se, então: se a luz não atuasse como parceira do iluminador na definição da atmosfera realista, a luz - realista - não teria existido para ser questionada pela crítica.

Afinal, mesmo que não tenha sido identificada como "parceira" pela crítica que abominou as atmosferas por ela criadas, e apontadas como a mácula realista, a luz precisou atuar como parceira do artista responsável por projetar essas mesmas atmosferas que geraram a desaprovação dos críticos e teóricos. É recomendável, por conseguinte, cuidado, ao se considerar atitudes teórico-críticas que apontam - por vezes localizadas na distância que resulta do desconhecimento - equívocos no trabalho de um artista.

E ainda, ao mencionar a atmosfera "sentimental" de um espetáculo realista, Roubine pode deixar escapar ligações com a abordagem romântica que antecedeu as iniciativas realistas que combateram esse "sentimentalismo". Talvez fosse bom dizer que se pode falar de um realismo romântico no qual a mencionada atmosfera sentimental podia ser aplicada. Aliás, pode-se até mesmo relacionar o tratamento sentimental da cena ao tom emocional do espetáculo simbolista que confrontou a imagem realista com proposições oníricas. Vale lembrar que, em muitos casos, a abordagem realista pode exigir recortes, composições de natureza gráfica, que deixariam extasiado um defensor da distorção expressionista. Ou seja, se, por um lado, é fácil compreender certas interpretações superficiais operadas pelo senso comum, por outro, determinadas nuanças do tratamento visual do espetáculo, notadamente no que se refere à luz, exigem da teoria e da crítica alguma atenção e cautela.

O texto a seguir inclui o tema do presente capítulo numa abordagem semiótica do espetáculo:

A encenação no Teatro Realista/Naturalista deve servir como um espelho da realidade, processo semelhante ao que ocorre com as outras manifestações artísticas e literárias do naturalis- 
mo. [...] A iluminação também deve ser fiel à realidade. Se é noite, escura; se é dia, clara. Se há um abajur, foco sobre ele quando estiver aceso. A luz do sol deve entrar pela janela descortinada. Além disso, a iluminação serve também para dar o clima ao Teatro Psicológico, fazendo com que os sentimentos das personagens possam ser perfeitamente compreendidos pela plateia. (FERNANDES, 2006, p. 6)

Ainda que seja perfeitamente possível compreender a boa intenção, afirmações dessa natureza podem dar lugar a questionamentos. Ao contrário do que propõe o texto, uma cena noturna pode exigir muito mais brilho - ou intensos fluxos luminosos projetados sobre o ambiente - e ainda contar com a interação luminância-iluminância, para que a luz artificial "substitua" a luz natural, tornando "claro" o ambiente, permitindo a visibilidade. E, se for feita uma escolha realista para um espetáculo cuja ação ocorra durante o dia, a iluminação (artificial) poderia ser dispensada, em muitos casos, já que o ambiente estaria "claro" o suficiente para que se enxergassem as pessoas, os objetos e o lugar. E mais, na abordagem realista, é possível indagar: por que projetar luz sobre um abajur, se ele é a fonte de luz? Pode-se argumentar, como já foi dito, que as sombras do abajur, tanto a sombra própria - aquela que incide sobre o próprio objeto - assim como a sombra projetada no ambiente, denunciariam a aplicação de um instrumento externo (um "refletor" teatral), destruindo a ilusão realista, devido às falsas sombras apresentadas na imagem. ${ }^{3}$

Como já foi dito, a sombra de um objeto define sua tridimensionalidade e, por conseguinte, sua presentificação no ambiente. Ora, no teatro, uma sombra que resultasse da incidência do fluxo luminoso de um "refletor" projetado sobre o mencionado abajur definiria uma intervenção "falsa" - no sentido realista - pois, se a lâmpada dentro do abajur não projetava tal sombra, como ela poderia estar visualmente presente? Mesmo que o iluminador não estivesse ciente disso, ele estaria criando um sutil estranhamento visual, atacando a "ilusão", sublinhando para o espectador sua presença em um teatro, assistindo a um espetáculo. Nesse sentido, a decisão de projetar a luz de um refletor sobre um abajur aceso, no palco, talvez seja a mais indicada para as inúmeras manifestações cênicas que combatem ou negam o realismo, e não para caracterizá-lo.

Abordagens teóricas superficiais podem, então, levar à desconsideração de aspectos determinantes nos espetáculos propriamente ditos. É necessário dizer

3 Cf. capítulo Rotas francesas para o teatro moderno, Figura go e comentário correspondente, quando se tratou da cena compartimentada, no século XII, na França. 
que o advento da luz elétrica ganhou importância nas iniciativas teatrais que combatiam o realismo desde o final do século XIX devido às possibilidades de efeitos que o controle fornecido pela eletricidade gradativamente permitiu. Aqui se encontra, no entanto, uma questão de maior amplitude, nem sempre identificada. Na verdade, muitos esquecem que o realismo no teatro pode ter tirado grande proveito da eletricidade. E é compreensível que isso não seja devidamente notado, pois, no espetáculo realista, ou em momentos realistas de espetáculos, a luz poderia atuar de modo tão sutil que, para olhos desavisados, pareceria difícil reconhecer sua presença. Um ambiente realista poderia solicitar um tratamento visual que tornaria a luz "invisível", o que poderia deixar indignado o espectador/crítico que só se interessa pela obviedade e, até, pela superficialidade visual dos efeitos.

\section{AVANÇOS TEATRAIS SOB A ÉGIDE DAS TECNOLOGIAS}

Uma possível hegemonia dos efeitos está certamente ligada a transições tecnológicas que ocorreram a partir do século XVIII e fizeram surgir novos aparatos, acessórios e sistemas de controle, cuja aplicação resultou em mudanças progressivas nos espetáculos.

Patenteada em 1780, a lâmpada Argand ${ }^{4}$ pode ser citada como um desses passos na mudança da visualidade na cena. A acomodação de um pavio cilíndrico num receptáculo (uma chaminé de vidro em forma tubular) que controlava o fluxo de ar, fazendo-o circular em torno do pavio e produzindo maior brilho da luz com mais estabilidade para a chama. A diferença pode ser sutil e parecer pouco ao olhar de hoje, acostumado a tanta diversidade. É possível, entretanto, imaginar uma luz menos "nervosa" e mais "brilhante" se comparada àquela resultante da oscilação das velas, assim como de outras luminárias a óleo. Ficava efetivada, assim, uma maneira diferente de ver a cena.

A lâmpada Argand exigiu esforços do pesquisador em busca de aperfeiçoamentos: a inovação do pavio acionado mecanicamente permitia controle da chama e, consequentemente, da intensidade da luz através de ajustes no seu movimento vertical. Na França, foi chamada de Quinquet depois de comercializada e, segundo alguns, aperfeiçoada pelo farmacêutico Antoine Quinquet (1745-1803). Sabe-se que o artefato passou por mudanças para contornar desvantagens como a agressivi-

4 Um aparato usado para produzir luz artificial, usando óleo como combustível, e cuja denominação se originou do nome de seu inventor, o cientista suíço Aimé Argand (1750-1803), estudioso da física e da química. Produzia brilho equivalente ao resultado alcançado pelo uso de várias velas - entre 6 e 10. 
dade da chama que podia danificar a chaminé de vidro; além disso, a dimensão do recipiente de óleo, que gerava uma importante área de sombra, impunha modificações. Ainda que a informação acerca da luz aplicada à cena, no início do século XIX na França, seja escassa, Bergman presume que o problema específico deve ter suscitado modificações da lâmpada Argand para implantar seu uso no teatro. É, então, presumível que pode ter sido instalada uma superfície refletora (réverbère) entre a chaminé e o depósito de óleo, desenvolvendo o princípio aplicado na Renascença italiana.

Outro passo importante da tecnologia foi alcançado com a luz a gás, repercutindo decisivamente no espetáculo teatral. (BERGMAN, 1977) Desde o final do século XVIII, um técnico da área da produção industrial de máquinas a vapor, William Murdoch (1754-1839), trabalhava em pesquisas, e iluminou a própria casa aplicando luz a gás, já em 1792.

O próprio Murdoch publicou no Nicholson's Journal, volume XXI (1808), relatos dos seus experimentos, comentando a produção de gases com a aplicação de diversas substâncias minerais e vegetais. Ele conduziu observações com a queima de carvão, usando também turfa, madeira, assim como outras substâncias inflamáveis. O depoimento de William Richards atesta a veracidade desses relatos:

Esse é o modesto e claro relato redigido pelo Sr. Murdoch sobre a origem e o progresso das primeiras tentativas acerca da luz a gás, cujas afirmações foram depois confirmadas pelo Dr. William Henry, de Manchester, e vários outros, também pelo Sr. James Watt Jr., mencionado adiante, o que não deixa possibilidade de dúvidas sobre a fidelidade da narrativa [...]. ${ }^{5}$ (RICHARDS, 1877, p. 11, tradução nossa)

Esse momento registrou a presença de outros interessados na mesma questão: na França, Phillipe Le Bon [ou Lebon] (1767-1804), na Suécia, C. Reuterona (?), e Fredrick Albert Wintzler ${ }^{6}$ (1763-1830), na Morávia. Com sucesso diferenciado, cada um deles buscou caminhos próprios, pesquisando, escrevendo e/ou divulgando alternativas para a aplicação da nova tecnologia, com particularidades em cada processo, mantendo o princípio da produção de aquecimento e/ou luz através do uso do gás. Richards (1877) assinala a presença da thermolampe (1801), um arte-

5 "Such is the modest and clear account given by Mr. Murdoch of the origin and the progress of the first attempt at gas lighting, which statements were further confirmed by Dr. William Henry, of Manchester, and various others, also by Mr. James Watt, jun., hereafter mentioned, thus leaving no possibility of doubting the accuracy of the above narrative."

6 Também grafado Winsor. 
fato desenvolvido por Le Bon, com o qual ele não alcançaria sucesso ao buscar sua produção em escala industrial e comercialização.

Depois de adquirir o monopólio da invenção de Lebon, C. Reuterona publicou um panfleto denominado Uma descrição da thermo lamp [A description of thermo lamp (1804)], mas recebeu grande resistência da Academia Real de Ciências de Estocolmo, que considerou a produção do invento muito cara e prejudicial à saúde. Fredrick Albert Wintzler estudou a invenção de Le Bon e, em 1803, proferiu uma palestra seguida de exibição, denominada Luz a gás (Gaslight), no Lyceum Theatre em Londres, mantendo sigilo sobre o processo de purificação do gás e sublinhando vantagens como a ausência de faíscas e de fumaça, além da intensidade e estabilidade da chama.

Na segunda década do século XIX, o invento creditado a Murdoch e a Wintzler foi progressivamente usado em ruas, hotéis e outras instalações, em Londres, originando uma rede de tubulação de gás. Vários artigos sobre o assunto já apareciam em revistas quando Fredrick Accum (1769-1838), que trabalhava na área da química publicou um texto detalhado acerca do tema, Um tratado prático sobre a luz a gás [A practical treatise on gas-light (1815)]. Seu trabalho inclui ilustrações sobre lâmpadas de diversos tipos e tamanhos (Figura 106), além de gasômetros [instalações para produzir e distribuir luz a gás, em média escala, para estabelecimentos comerciais e industriais]. A regularização do seu uso originou diferentes opiniões, e dentre as vantagens na comparação com a luz a óleo apareceram o maior brilho (cerca de 10 vezes mais) e mais estabilidade da chama, o que gerava uma luz suave e difusa, além da ausência (ou redução) de odor e fuligem.

Há controvérsias sobre autoria e datas nos relatos e documentos que tratam das primeiras incursões na pesquisa com luz a gás. Os nomes de Lebon e Wintzler parecem por vezes grafados como Winsor e Le Bon, sem qualquer advertência. A tradução para a língua portuguesa de parte do capítulo quatro, A história da iluminação (The history of illumination), do livro de Jean Rosenthal e Lael Wertenbaker, A magia da luz (The magic of light), publicada na revista Cadernos de teatro n. 102, de 1984, informa que a primeira aplicação do gás no teatro se deu em 1806, sob a responsabilidade de F. A. Wintzler, a quem a tradução se refere como iluminador, enquanto os autores dizem apenas se tratar de um "alemão". (ROSENTHAL; WERTENBAKER, 1972)

Parece pouco recomendável aplicar o título de iluminador para caracterizar a função de um profissional específico, naquele momento do teatro. Além disso, é 
possível questionar a correção dessa data, 1806. Outras fontes, como Bill Williams, ${ }^{7}$ indicam 1816 como o ano no qual se registra a instalação no Chestnut Theatre, na Filadélfia, do primeiro sistema de luz a gás no teatro. Bergman (1977), por sua vez, consultando os jornais londrinos The Examiner e The Times de setembro de 1817 diz que em agosto do mesmo ano o palco do Lyceum Theatre recebeu luz a gás em 1817 e, um mês depois, o Theatre Drury Lane, também em Londres, já operava com o mesmo tipo de sistema. De qualquer maneira, parece consenso que ao final da segunda década do século XIX a luz a gás já havia introduzido significativas mudanças nos espetáculos.

A despeito do confirmado risco de incêndio como a maior desvantagem da luz a gás, sua aplicação repercutiu de modo crescente no teatro, sendo documentada em textos como a criteriosa descrição publicada no Theater-Lexicon, de Leipzig, em 1841 e escrita por Ph. J. Dürringer e H. Barthels, que inclui ponderações importantes:

De modo geral, a luz a gás na sua forma mais pura produz uma luz branca, algo amarelo-avermelhada (quanto mais puro o gás, mais branca a luz) que, comparada à luz de uma boa lâmpada Argand difere em brilho e cor, assim como essa lâmpada é diferente [apresenta melhor resultado] de uma vela de boa qualidade, [...]..$^{8}$ (DÜRRINGER; BARTHELS apud BERGMAN, 1977, p. 259, tradução nossa)

Ficava evidente um incremento na temperatura de cor, que mais tarde seria progressivamente ampliado com a luz elétrica, pela aplicação da fluorescência e, recentemente, do LED. Outra vantagem relacionada ao uso do gás refere-se à geração da chama propriamente dita que dispensava o cuidado com resíduos, como no caso das velas; além disso, a comparação com a lâmpada a óleo mostrava grande diferença, pois, nesta última a carbonização do pavio provocava mais odor e fumaça.

No teatro, o uso de sistemas mecânicos para transportar o fluxo de gás pelo emaranhado de tubos até os bicos queimadores [de formas e tamanhos diversos] definia a qualidade da chama, permitindo controle da intensidade, mudanças suaves e maior precisão. Isso incluía cores aplicadas a diferentes áreas da cena, através de uma central de operações [que Bergman chama gas-table ou, mesa de gás].

7 Disponível em: 〈http://www.mts.net/ william5/history/hol.htm〉. Acesso em: 12 jun. 2009.

8 "On the whole, gaslight in its purest form has a white, some what yellowish red light (the purer the gas, the writer the light) which, compared with the light of a good Argand lamp is different from it in brightness and colour just as this lamp is different from a good candle, [...]." 
Tais aspectos, em conjunto com novas estruturas de sustentação para instrumentos de luz como varas acima do palco, determinaram o surgimento dos novos sistemas para aplicação da luz no teatro, cuja flexibilidade contribuiu para o amadurecimento das relações técnico-estéticas.

\section{A CENA SOB CONTROLE}

De acordo com Bergman (1977), Richard Wagner (1813-1883) teria comentado um incidente que se transformaria num importante aspecto da sua obra: na abertura do Festspielhaus de 1876, no Bayreuth (Alemanha), por falta de revisão final do ajuste definido para o sistema de iluminação a gás, a plateia ficou praticamente às escuras do início do espetáculo, chocando os espectadores. Ainda segundo Bergman, Wagner corrigiu o equívoco, nos espetáculos seguintes, mas fez o público mergulhar numa considerável penumbra; o evento teria contribuído para a difusão dessa prática na maioria dos teatros da Alemanha, e deixado um importante legado que deveria servir como aprendizado, ainda hoje. Constatou-se que, mesmo com o avanço tecnológico, o iluminador não é uma de entidade infalível; se os envolvidos em um espetáculo dependem de muita experimentação e ensaios parece incongruência solicitar que o "iluminador" chegue alguns dias antes da estreia - por vezes, nem tanto - e resolva a luz, como num passe de mágica ou ato místico: faça-se a luz!

Mesmo com rumores acerca dos espetáculos do ator inglês Charles Kean (1811-1868), no Princess Theatre, em Londres, nos quais a plateia teria permanecido praticamente às escuras durante os espetáculos, muitos dizem que Wagner teria encaminhado o controle deliberado da luz na plateia. Era impossível, no entanto, mesmo na era do gás, extinguir completamente a luz - na plateia ou no palco uma vez que seria necessário voltar a acionar os instrumentos de iluminação, fossem velas, lamparinas a óleo ou bico de gás. Aí residiria o principal avanço surgido no final do século XIX, quando vários pesquisadores estudaram a produção da luz elétrica.

Na verdade, experimentos com a eletricidade têm sua história documentada desde a Antiguidade, quando os gregos, provavelmente na cidade de Magnésia, ${ }^{9}$ no século VI a.C., tiveram sua curiosidade despertada por uma pedra que atraía pedaços de ferro, denominando-a magneto. Tales de Mileto (624/625-556/558 a.C.), sábio considerado pioneiro da filosofia ocidental, teria desenvolvido experimen-

9 Localizada na região da Tessália, ou um dos vários lugares denominados Heraclea. 
tos com outras substâncias, entre elas o âmbar - ou elektron, em grego; electrum, em latim - uma substância vítrea, que teria originado o termo eletricidade e suas derivações.

No seu diálogo Ion, entre Sócrates e o rapsodo cujo nome originou o título da obra, Platão menciona o magneto para tratar da inspiração poética:

SÓCRATES: Compreendo, Ion: e explicarei o que imagino seja a razão para isso. Essa habilidade que você detém de falar tão bem, sobre Homero, não é uma arte, mas, como eu disse, uma inspiração; há uma divindade que te move, como aquela contida na pedra que Eurípedes chama magneto, mas que é conhecida como pedra de Heraclea. Ela não apenas atrai anéis de ferro, mas, também, dá a eles um poder similar de atrair outros anéis; e, às vezes, você pode ver vários pedaços de ferro, suspensos sobre outros, de modo que formam uma longa corrente: e todos eles têm seu poder de suspensão derivado da pedra original..$^{10}$ (PLATO, 2008, p. 9, tradução nossa)

A despeito dos inúmeros comentários acerca dessa relação entre as capacidades magnéticas das substâncias e a inspiração que provoca os poetas, localizada além da instância das habilidades, impressiona em Platão a qualidade visual da exegese. Ele estabelece uma analogia entre a mencionada inspiração poética e uma corrente de anéis unidos por algum tipo de energia que se desloca entre eles. O termo eletricidade só apareceu muito mais tarde, quando, no século XVII, William Gilbert (1540-1603), físico inglês e médico da Rainha Elisabeth I, chamou "elétricas" todas as substâncias que atraíam outras, depois de submetidas à fricção. Diversas outras experiências relacionam a história da humanidade à propriedade elétrica das substâncias.

Várias pesquisas foram empreendidas nos séculos que se seguiram, estudando-se as cargas elétricas, as possibilidades de carregar corpos com eletricidade e de conduzir o fluido elétrico. Os estudos levaram os pesquisadores a concluir que todo corpo tem certa quantidade do fluido elétrico, mas nem todo corpo se comporta como condutor, e não atrai, portanto, nenhum outro. No processo de fricção de um corpo, determinada quantidade de fluido elétrico é perdida,

\footnotetext{
10 "I perceive, Ion; and I will proceed to explain to you what I imagine to be the reason of this. The gift which you possess of speaking excellently about Homer is not an art, but, as I was just saying, an inspiration; there is a divinity moving you, like that contained in the stone which Euripides calls a magnet, but which is commonly known as the stone of Heraclea. This stone not only attracts iron rings, but also imparts to them a similar power of attracting other rings; and sometimes you may see a number of pieces of iron and rings suspended from one another so as to form quite a long chain: and all of them derive their power of suspension from the original stone."
} 
ou passa por ele, resultando numa quantidade maior ou menor do que aquela presente no corpo "em repouso", produzindo carga positiva ou negativa. Objetos com carga positiva tendem a se repelir, assim como aqueles que têm carga negativa repelem os da mesma natureza.

No século XIX, entretanto, as investigações alcançaram um ponto que introduziria resultados inovadores no teatro. Em 1809, o químico inglês Humphry Davy (1778-1829) apresentou aquele que ficou conhecido como o primeiro artefato concebido para produzir luz artificialmente com a aplicação da eletricidade, conectando dois fios em uma bateria e ligando uma tira de carvão vegetal entre as outras extremidades dos fios. Como resultado da carga, o carvão brilhava, originando a primeira lâmpada de arco elétrico. Desde o surgimento desse aparato muitas outras pesquisas foram encaminhadas em busca de uma "lâmpada elétrica", o que torna difícil mencionar isoladamente um inventor.

A lâmpada incandescente que se afirmaria no fim do século XIX como fonte de luz artificial, de eficiência sem concorrente naquele momento, foi incrementada em um artefato constituído de filamento, bulbo de vidro, base de contato, gás e lacre (Figura 107). Vários pesquisadores contribuíram para o desenvolvimento de cada um desses componentes, o que originou demandas variadas pela exclusividade ou autoria da invenção. Nos Estados Unidos da América, nomes como os de Moses Gerrish Farmer (1820-1893), William Sawyer (?), Albon Man (?) e Hiram Stevens Maxim (1840-1916), assim como o de George Lane-Fox (?) na Inglaterra, estiveram ligados a iniciativas que buscavam uma lâmpada incandescente de filamento durável, o que gerou muitas disputas. Uma das mais notáveis controvérsias envolveu Thomas Edison (1847-1931) e Joseph Wilson Swan (1828-1914), (1828-1914), que depois se associaram fundindo suas empresas na Edison and Swan United Electric Light Company Limited, em 1883.

Já no final do século XIX a eficiência e o controle da luz elétrica, quando comparados às tecnologias que os antecederam, promoveriam importantes mudanças no teatro. A segunda metade do século XIX representou um momento de grande efervescência no ambiente teatral. Relações diretas entre tecnologia e pensamento repercutiram na práxis cênica, trazendo possibilidades nunca vistas antes. Em 1881, foi instalado no Savoy Theatre, de Londres, o primeiro sistema de luz elétrica numa casa de espetáculos. Era um total de 824 lâmpadas de 16 watts para o palco e 334 para a plateia. No ano seguinte, o Bijou Theatre da cidade norte-americana de Boston recebeu sua primeira iluminação elétrica, que tomaria o lugar da luz a gás na grande maioria dos teatros a partir de então. Em 1903, a Metropolitan 
Opera House de Nova Iorque recebeu um sistema que controlava um conjunto de 116 dimmers, ${ }^{11}$ incluindo a luz de plateia, instalado pela empresa Kliegl Brothers. ${ }^{12}$

O uso da luz elétrica no teatro é até apontado pelo estudioso francês JeanJacques Roubine como importante fator para o que ele denomina o nascimento do teatro moderno. Roubine considera decisivo o contato que se estabelece entre certos artistas europeus, cujas viagens a países estrangeiros promoveram grande intercâmbio de conhecimento. A isso ele alia a difusão de pesquisas teóricas e práticas, fazendo circular ideias que resultam de inquietações do pensamento emergente de base científica, cujo interesse na hereditariedade e no ambiente como determinantes para a construção da natureza humana encaminhou novas abordagens da obra de arte. Para Roubine, a contribuição da luz elétrica forneceu ferramentas indispensáveis à revolução que se implantou no teatro da transição entre os séculos XIX e XX.

\section{ÉMILE ZOLA E A LUZ IMPOSSÍVEL}

O interesse pela influência direta do ambiente na formação do ser humano repercutiu de modo decisivo no teatro francês, incluindo o trabalho teórico de Émile Zola (1840-1902), quando ele fundamenta seu teatro naturalista, que considera "o movimento da inteligência do século [XIX]”33 (ZOLA, 1881, p. 42, tradução nossa), declarando a influência direta da crise social derivada da Revolução Francesa. De modo sintomático, Zola dedica à dramaturgia grande parte dos seus escritos acerca do naturalismo no teatro, deixando uma pista clara sobre a relevância do texto na estética teatral em discussão. Dentre as várias definições do movimento, ele declara: "[...] [o naturalismo] consiste, simplesmente, na aplicação do método experimental ao estudo da natureza e do homem".14 (ZOLA, 1881, p. 43, tradução nossa) Sua teoria parece ligada à necessidade de introduzir a observação e o experimento à literatura, configurando um procedimento científico moderno.

Segundo Zola (1881), no teatro naturalista a linguagem deveria banir o lirismo romântico impregnado de certa confusão, de certo desequilíbrio, para prover

\footnotetext{
11 Artefato destinado ao controle da intensidade de luz no palco, cuja tecnologia vem se modificando, desde o final do século XIX.

12 John H. Kliegl (1869-1959) e Anton Tiberian Kliegl (1872-1927), inventores e fundadores da Universal Electric Stage Lighting Company, de Nova York, que permaneceu ativa desde 1896 até 1990.

13 "[...] le mouvement de l'intelligence du siècle."

14 “[...] qu'il consistait simplement dans l'application de la methode expérimental à l'étude de la nature et de l'homme."
} 
um estilo cujos alicerces estavam na lógica e na clareza, cuja construção é científica e natural, lidando com a palavra fundamentada na verdade. Um legado da linhagem cujas bases já haviam sido lançadas na França por Diderot. Considerada pelos seus críticos contemporâneos uma manifestação próxima da obscenidade, a linguagem naturalista pretendia confrontar a fala idealista baseada na retórica e na sublime "loucura lírica".

Desse modo, Zola acreditava que o naturalismo encontrou no romance sua mais importante forma de expressão, até porque o teatro guarda circunstâncias muito específicas nas suas convenções que podem criar limites para uma proposta tão radical, desenvolvida da fórmula deixada por Honoré de Balzac (1799-1850) e Stendhal (Henri-Marie Beyle, 1783-1824). Zola viu essa reação ao romantismo na obra de Gustave Flaubert (1821-1880) que teria amadurecido e completado a forma naturalista revelando-se, em sua opinião, um artista perfeito. O debate sobre as diferenças entre o romance e a dramaturgia já vinha sendo travado pela crítica que apontava divergências justificadas pelas diferentes possibilidades de cada uma dessas formas expressivas da literatura, já que o romancista desfrutava de um grau de liberdade com o qual o dramaturgo não podia contar.

Émile Zola não poupou esforços, e até parece redundante na sua intenção de esclarecer os pressupostos naturalistas, nos quais o autor está proibido de emitir julgamentos e apenas relata. Suas assertivas são contundentes: "Não há mais lugar para a imaginação, o enredo tem pequeno valor para o romancista, que não se envolve com o desenvolvimento, o mistério ou o desfecho; quer dizer, ele não intervém para subtrair [da realidade] ou adicionar à realidade, [...]".15 (ZOLA, 1881, p. 124, tradução nossa) Ainda tratando da construção dramática, ele menciona o palco, e aponta o que deve ser posto em cena:

Em lugar de imaginar uma aventura, de complicá-la, de fazer um arranjo de efeitos de palco cuja sucessão de cenas levará a uma conclusão, toma-se, simplesmente, o estudo da vida de uma pessoa ou grupo de pessoas, cujas ações são retratadas fielmente. A obra torna-se um relatório, nada mais. ${ }^{16}$ (ZOLA, 1881, p. 124, tradução nossa)

\footnotetext{
15 “L'imagination n'a plus d'emploi, l'intrigue importe peu au romancier, qui ne s'inquiète ni de l'exposition ni du noeud, ni du dénouement; j'entends qu'il n'intervient pas pour retrancher ou ajouter à la réalité, [...]."

16 "Instead of imagining an adventure, of complicating it, of arranging stage effects, which scene by scene will lead to a final conclusion, you simply take the life study of a person or a group of persons, whose actions you faithfully depict. The work becomes a report, nothing more."
} 
A dramaturgia que se encaminhava ao naturalismo era, para Zola, representada por autores acerca dos quais ele tinha opiniões diversificadas: no trabalho de Victorien Sardou (1831-1908), Zola criticava a observação da vida, que lhe parecia superficial; da obra de Alexandre Dumas, filho (1824-1895), ele destacava a disposição de sacrificar a exigência cênica, em nome da realidade; o texto de Émile Augier (1820-1889), na opinião de Zola, acentuava a capacidade que a prosa demonstrava de retratar a sociedade. Aquilo que Zola denominava teatro naturalista era caracterizado, até então, pelo trabalho de autores, de dramaturgos, o que pode servir como diagnóstico para que se compreenda a imposição de um papel hierárquico da dramaturgia no contexto teatral. Tal constatação se evidencia na sua referência ao espetáculo propriamente dito: "O palco sempre foi a última cidadela da convenção [...]". ${ }^{17}$ (ZOLA, 1881, p. 141, tradução nossa) Com isso, ele pretendia identificar as dificuldades e apontar caminhos para a implantação da fórmula naturalista no espetáculo. Afinal, incorporando rebeldia radical, o palco impõe tempo e espaço próprios que representariam enormes entraves para a exposição da observação do ser humano e da natureza tal qual aquela permitida no romance. Por outro lado, Zola desafiava o teatro e até deixou uma firme assertiva:

[...] a fórmula naturalista, ainda que completa e definida no romance está muito longe de ocupar o teatro, e eu concluo que isso se concretizará, que ele assumirá, cedo ou tarde, o rigor científico; caso contrário, o teatro se achatará, tornando-se, mais e mais, inferior. ${ }^{18}$ (ZOLA, 1881, p. 141, tradução nossa)

Sua forte convicção da necessidade de tratamento científico da cena aplicando a fórmula já vitoriosa no romance impunha que se levasse ao palco, sem as "mentiras idealistas" do romantismo, um homem de carne e osso observado cientificamente na realidade. Tal convicção esbarrava em aspectos práticos, na natureza teatral mesma, e em questões técnicas das convenções contemporâneas do seu teatro: "Em uma palavra, o palco é o domínio da convenção, tudo permanece convencional, desde o cenário, desde a ribalta que ilumina os atores de baixo para cima, até as personagens que são movimentadas por um cordão."19 (ZOLA, 1881, p. 144, tradução nossa)

\footnotetext{
17 "Le théâtre a toujours été la dernière citadelle de la convention, [...]."

18 "[...] la formule naturaliste, désormais complète et fixée dans le roman, est très loin de l'être au théâtre, et j'en conclus qu'elle devra se compléter, qu'elle y prendra tôt ou tard sa rigueur scientifique; sinon le théâtre s'aplatira, deviendra de plus en plus inférieur."

19 "En un mot, le théâtre est le domaine de la convention, tout y reste conventionnel, depuis le décors, depuis la rampe qui éclaire les acteurs par en bas, jusqu'aux personnages qu'on y promène au bout un fil."
} 
Além de qualificar como marionetes os atores que apenas "passavam pela cena", com o objetivo de declamar textos que lhe eram designados, essa é uma, dentre as raras menções que Zola (1912, p. 89, tradução nossa) faz à luz, reprovando a ribalta. Ele disse, também:

Seria um absurdo crer que se poderá transportar a natureza, tal qual ela é para os palcos, plantar árvores verdadeiras, ter [no palco] casas verdadeiras, iluminadas por verdadeiros sóis. As convenções são, portanto, necessárias, temos que aceitar as ilusões mais ou menos perfeitas, em lugar das realidades. ${ }^{20}$

Zola (1881, p. 89, tradução nossa) sublinhou, ainda, um problema de enorme importância, sem, no entanto, vislumbrar objetivamente soluções, dados os limites que a tecnologia impunha:

A questão dos cenários e dos acessórios é um excelente terreno, circunscrito e claramente delimitado para trazer o estudo das convenções no palco. Resumindo, as convenções representam grande questão. Alguns me dizem que as convenções são eternas, que a ribalta jamais será suprimida, que sempre haverá tapadeiras pintadas, que, na cena, as horas serão contadas como minutos, que as salas onde as peças se passam não terão mais que três paredes. ${ }^{21}$

Zola insistiu em sublinhar o incômodo que a luz da ribalta lhe provocava, mas não parecia ter soluções para bani-la. Portanto, lhe parecia mostrar os experimentos (espetáculos) com a estranha luz em ângulo ascendente nela originada e assumir a visualidade equivocada:

O infortúnio, eu disse, é que queremos colocar o teatro de lado considerando-o uma essência absolutamente diferente. Há, sem dúvida, sua óptica. Mas não o vimos todo o tempo obedecer ao movimento da época? Nesse momento, o cenário exato é uma consequência da necessidade de realidade que nos atormenta. É inevitável que o teatro ceda a esse impulso, quando o romance não é mais que uma investigação universal, [...].

\footnotetext{
20 “Il serait absurde de croire qu'on pourra transporter la nature telle quelle sur les planches, planter de vrais arbres, avoir de vraies maisons, éclairées par de vrais soleils. Dès lors, les conventions s'imposent, il faut accepter des illusions plus ou moins parfaites, à la place des réalités."

21 "La question des décors et des accessoires est un excellent terrain, circonscrit et nettement délimité, pour y porter l'étude des conventions au théâtre. En somme, les conventions sont la grosse affaire. On me dit que les conventions sont éternelles, qu'on ne supprimera jamais la rampe, qu'il y aura toujours des coulisses peintes, que les heures à la scène seront comptées commes des minutes, que les salons où se passent les pièces n'auront que trois murs."
} 
Nossas personagens modernas, individualizadas, que agem sob o império de influências do ambiente, que vivem nossa vida na cena, ficariam completamente ridículas em cenários do século XVII. Elas sentam, e precisam cadeiras; elas escrevem, e precisam mesas; elas se deitam, elas se vestem, elas comem, elas se aquecem, e precisam de um mobiliário completo. Por outro lado, nós estudamos todos os mundos, nossas peças caminham por todos os lugares imagináveis, [mas] os mais variados quadros devem forçosamente desfilar diante da ribalta. Essa é uma necessidade da nossa fórmula dramática [do teatro] atual. ${ }^{22}$ (ZOLA, 1881, p. 84-85, tradução nossa)

Afinal, o naturalismo necessitava da força do teatro, capaz de alcançar de uma só vez, num período de três horas, centenas e até milhares de espectadores, enquanto que o romance limitava-se a um solitário leitor. É possível compreender tal concessão, no caso de Zola, quando se leva em consideração os mencionados limites tecnológicos. Mas não é incomum encontrar, ainda hoje, espetáculos cujo tratamento visual parece aquém do que se poderia prever, mais de um século depois que ele escreveu suas inquietações. Os motivos atuais são outros, dentre eles, a limitação dos orçamentos. Mesmo assim, certos espetáculos parecem incluir no elenco das razões para uma visibilidade apenas sofrível, o desconhecimento - gerado pelo difícil acesso à formação específica - e o descaso, também muito grave. Fica uma impressão: o objetivo é, por vezes, reduzido a apenas mostrar algo no espaço cênico pouco importando o cuidado que deve inserir na práxis cênica o grau de excelência visual exigido pela sua natureza artística.

Mas Zola parecia convencido que o teatro acabaria por acompanhar a "evolução" alcançada pelo naturalismo. Mesmo com as limitações que enfrentava, ele acentuava a necessidade do estabelecimento de um ambiente no qual se pudesse acreditar, como condição para que se apresentasse em cena o ser humano "real e verdadeiro", que ele considerava o tema por excelência do teatro. Nesse ponto, Zola era tão honesto, sério e revolucionário quanto um jovem performer do século

22 “Le malheur, ai-je dit; est qu'on veut mettre le théâtre à part, le considérer comme d'essence absolument différente. Sans doute, il a son optique. Mais ne le voit-on pas de tout temps obéir au mouvement de l'époque? A cette heure, le décor exact est une consequence du besoin de réalité qui nous tourmente. Il est fatal que le théâtre cède à cette impulsion, lorsque le roman n'est plus lui-même qu'une enquête universelle, [...]. Nos personnages modernes, individualisés, agissant sous l'empire des influences environnantes, vivant notre vie sur la scène, seraient parfaitement ridicules dans le décor du dix-septième siècle. Ils s'asseoient, et il leur faut des fauteuils; ils écrivent, et il leur faut des tables; ils se couchent, ils s'habillent, ils mangent, ils se chauffent, et il leur faut un mobilier complet. D'autre part, nous étudions tous les mondes, nos pièces nous promènent dans tous les lieux imaginables, les tableaux les plus varies doivent forcément défiler devant la rampe. C'est là une nécessité de notre formule dramatique actuelle." 
XXI, que nega as grandes narrativas responsáveis por confirmar a presença da realidade funcional no palco, da construção psicológica, do conflito (drama), e até, da personagem. Ambos querem provocar o ser humano, com a discussão da sua natureza mesma, cada um acreditando no seu próprio caminho, como clama Zola (1881, p. 142-143, tradução nossa):

Espero que sejam postos de pé no teatro homens de carne e osso retirados da realidade e analisados cientificamente, sem uma mentira. Espero que nos desembaracemos das personagens fictícias, desses símbolos convencionais da virtude e do vício, sem qualquer valor como documentos humanos. Espero que o meio determine as personagens e que as personagens ajam de acordo com a lógica do seu próprio temperamento. [...] Espero, enfim, que a evolução que ocorreu no romance alcance o teatro, fazendo-o voltar-se para a ciência e para a arte moderna, para o estudo da natureza, da anatomia do ser humano, da pintura da vida, [...] o mais original e poderoso, como ninguém ousou antes arriscar sobre o palco. ${ }^{23}$

A experimentação teatral de um homem de carne e osso exigia que o ambiente no qual ele agisse fosse apresentado de modo fiel e convincente. Diferentemente do argumento usado pela crítica e apontado por Zola, o conflito não pode estar somente no ator, desconsiderando o tratamento espacial específico. Mesmo que se use Shakespeare e Molière como justificativa, Zola rebate, afirmando que ele tratava de outro tempo e de um novo entendimento do ser humano para o qual o ambiente é determinante.

Um cenário que não tem valor dramático, que é como uma curiosidade à parte, posto lá para deslumbrar o público, degrada uma obra, pondo-a em um nível inferior de magia [...]. Em uma palavra, o cenário pelo cenário, mesmo rico e curioso, é apenas uma especulação e nada mais faz do que estragar uma obra literária. ${ }^{24}$ (ZOLA, 1912, p. 96, tradução nossa)

\footnotetext{
23 “J'attends qu'on plante debout au théâtre des hommes en chair et en os, pris dans la réalité et analysés scientifiquement, sans un mensonge. J'attends qu'on nous débarrasse des personnages fictifs, de ces symboles convenus de la vertu et du vice qui n'ont aucune valeur comme documents humains, J'attends que les milieux déterminent les personnages et que le personnages agissent d'après la logique de leur prope temperament. [...] J'attends enfin que l'evolution faite dans le roman s'achève au théâtre, que l'on y revienne à la source même de la science et de l'art modernes, à l'étude de la nature, à l'anatomie de l'homme, à la peinture de la vie, dans un procès-verbal exact, d'autant plus original et puissant, que personne encore n'a osé le risquer sur les planches."

24 "Un décor qui n’a pas d'utilité dramatique, qui est comme une curiosité à part, mise là pour éblouir le public, ravale un ouvrage au rang inférieur de la féerie et du mélodrame à spectacle. En un mot, le décor pour le décor, si riche et si curieux soit-il, n'est qu'une spéculation et ne peut que gâter une oeuvre littéraire."
} 
Zola reconhecia a necessidade da artificialização na execução dos cenários, e apontava a capacidade dos artistas [pintores cenógrafos, como ele chamava] de criar resultados convincentes com papel, tecido e madeira. Além disso, ele já vislumbrava tendências pioneiras na técnica cenográfica, que criavam caminhos para a elaboração do cenário naturalista, no qual todos os móveis e acessórios deviam estar presentes. Tal necessidade era justificada na surpresa que deve tomar conta do espectador, incapaz de prever o desenvolvimento da ação já que não saberá que elementos cenográficos serão usados, a cada ocorrência da ação. Por outro lado, tais exigências com a cenografia, aliadas à impotência para superar a falta de recursos técnicos na criação da luz para a elaboração de ambientes "verdadeiros", determinavam um inevitável grau de desconhecimento, de ignorância, tornando a cena naturalista uma incompletude estética, uma contradição insolúvel, àquele momento.

Ainda que se possa dizer muito mais sobre as proposições teóricas de Émile Zola, à presente abordagem basta sublinhar essa sintomática contradição. Afinal, se o ambiente é fator conclusivo na elaboração do ser humano, vale lembrar que a luz é aspecto decisivo na construção do ambiente, do lugar, no modo como o ser humano percebe e age no ambiente, assim como na sua apreensão do outro e na interação particular com o ambiente que ambos ocupam. Diante dos enormes limites tecnológicos, portanto, atender aos pressupostos naturalistas no que se refere aos resultados precisos da observação e experimentação científicas da luz natural e/ou artificial - representava enormes desafios.

Considerem-se as demandas da visualidade: diante de uma luz de ribalta, da impossibilidade tecnológica de criar ângulos, cores e texturas que retratassem o que se podia observar no ambiente construído e/ou ocupado pelo ser humano, a experimentação naturalista da luz parecia limitada a permanecer encarcerada no romance e na teoria de Zola. No entanto, a ousadia de outro artista francês, André Antoine (1858-1943), validou o desejo de levar à cena as iniciativas radicais dessa estética fundada em pressupostos científicos ou, nas palavras do próprio Zola (1881, p. 128, tradução nossa): "Não somos mais que estudiosos que analisam, que pesquisam a anatomia, [...] e nossas obras são a certeza, a solidez e as aplicações práticas das obras da ciência". 25

25 "Nous ne sommes que des savants, des analystes, des anatomistes, [...] et nos ouevres sont la certitude, la solidité et les applications pratiques des ouvrages de science." 


\section{ANDRÉ ANTOINE E A CENA COMO REALIDADE CONTROLADA}

Indignado com o sistema implantado no teatro francês da sua época André Antoine repudiava àquilo que via nos palcos, incluindo o que ele considerava o monopólio da "trindade", composta por Émile Augier (1820-1889), Alexandre Dumas, filho (1824-1895), e Victorien Sardou (1831-1908), que recebia o reforço de Eugène Scribe (1791-1861), cuja fórmula da peça bem-feita ${ }^{26}$ (pièce bien faite) era incorporada por grande parte dos dramaturgos. Antoine acreditava que a saída estava na busca de novos autores, cujas obras estivessem livres de vínculos com o teatro comercial, que impunha o desejo dos produtores. Isso o aproximou de Émile Zola cuja teoria do teatro naturalista repercutiria nos seus espetáculos. Assim como Zola, outros novos autores foram encenados por Antoine, entre eles Edmond de Goncourt (1822-1896), além de dramaturgos de outros países: Henrik Ibsen (1828-1906), Léon Tolstoi (1828-1910), Ivan Tourguéneff [ou Ivan Sergeyevich Turgenev, (1818-1883)]. Para Antoine, os espetáculos franceses eram montados em torno da figura centralizada de uma estrela com altos salários e rodeada por atores ruins recrutados aleatoriamente. Ele resume o resultado:

Dessa interpretação heterogênea resulta uma deformação absoluta da obra [texto dramático], causa de uma nova e irremediável repulsa do público inteligente. | Em resumo, o teatro atual oferece ao espectador peças desinteressantes, em teatros pessimamente administrados, a preços exorbitantes, interpretadas por companhias sem coesão. ${ }^{27}$ (ANTOINE, 189o, p. 26-27, tradução nossa)

Ainda criança, Antoine acostumou-se a frequentar o Ba-ta-clan, ${ }^{28}$ onde assistia comédias e operetas, levado pela mãe. Mais tarde, influenciado por um amigo, interessou-se pelo movimento artístico, frequentando livrarias, teatros, a Escola de Belas Artes, os museus e, segundo seu próprio depoimento, decorava as falas

\footnotetext{
26 A fórmula da peça bem-feita é atribuída à Eugene Scribe, que a teria desenvolvido a partir de 1825, seguindo pressupostos técnicos muito claros, que determinavam uma estrutura constituída de enredo artificialmente elaborado, um clímax no qual os conflitos eram resolvidos e um final feliz.

27 “De cette interprétation hétéroclite résulte une absolute déformation de l’oeuvre, d’où nouvelle et irrémédiable cause de répulsion pour le public intelligent. | En résumé, le théâtre actuel offre au spectateur des pièces sans intérêt, dans des salles déplorablement agencées, à des prix exorbitants, avec des troupes sans cohésion."

28 Um café-concerto localizado nos arredores de Paris, cujo programa incluía vaudevilles de Eugène Scribe, Jean-François Alfred Bayard (1796-1853), Anne-Honoré-Joseph Duveyrier Mélesville (1787-1865) e Théophile Marion Dumersan (1780-1849). Antoine declara, nas suas Memórias sobre o teatro livre, que as mais importantes impressões em sua mente de criança foram deixadas por representaçõeos de Beaumarchais (Pierre-Augustin Caron de Beaumarchais, 1732 -1799). (ANTOINE, 1921, p. 9-10)
} 
das principais estrelas da Comédie Française, enquanto seu gosto pela carreira de ator se desenvolvia. Ele frequentou um curso de dicção no qual estabeleceu contato com os grandes clássicos tentando depois, sem sucesso, ingressar no Conservatório de Paris onde se estudava música, dança e o teatro francês de bases então tradicionais. Convocado para o exército, permaneceu na Tunísia entre 1878 e 1883. Três anos depois do seu retorno, ingressou no Cercle Gaulois, uma associação de atores amadores comum àquela época em Paris que apresentava modestos espetáculos mensais destinados a parentes e amigos.

Antoine sentia-se incomodado pelo aparente sucesso de uma associação vizinha, concorrente e com muito mais recursos financeiros, a Cercle Pigalle. Ele acreditava que o caminho para o teatro que lhe interessava partia da descoberta de novos autores. Um amigo, Arthur Byl, lhe indicou contatos que findaram por promover encontros com um grupo de autores, denominado Les soirées de Médan, cujo nome originou-se no lugar, Médan, perto de Paris, onde ficava a casa de Émile Zola. Lá se reuniam seis autores, o que acabou por originar a publicação, em 1880, de uma coletânea de seis contos, cujos temas se referiam à guerra franco-prussiana, um de cada membro do grupo. Émile Zola, Guy [Henry-René-Albert-] de Maupassant (1850-1893), Joris-Karl Huysmans (1848-1907), Henry Céard (18511924), Léon Henrique (1850-1935) e Paul Alexis (1847-1901).

Daí derivou uma indicação de Henrique, que enviou para Antoine o manuscrito de uma adaptação (ou uma versão dramática) do romance de Zola, Jacques Damour, cuja proposta de montagem havia sido recusada pelo Odéon. O entusiasmo de Antoine pelo novo texto não contagiou a totalidade dos membros do Cercle Gaulois levando-o a assumir toda a responsabilidade, inclusive financeira, de representação da peça, mesmo sem ter um centavo para investir. Esses eventos deram origem ao Théâtre Libre (cujo título final foi uma sugestão de Arthur Byl, depois de uma indicação de Antoine, cuja busca se dirigia mais para uma epígrafe do que para um título, cunhando "Le Théâtre en liberté", emprestado de Victor Hugo, segundo ele mesmo declara). Byl teria exclamado em um brinde: "Alors, le Théâtre Libre!" (ANTOINE, 1921, p. 23) originando a denominação que hoje se conhece. Sobre esses momentos, Antoine (1921, p. 18, tradução nossa) confessa: "Eu, por minha conta, não tinha o menor desejo de me tornar um ator ou diretor profissional e teriam me feito rir se tivessem antecipado que nós iríamos revolucionar a arte dramática". 29

29 “Pour mon compte, je n'avais pas le moindre dessein de devenir un acteur ou directeur professionnel et l'on m’eût bien fait rire si l'on m'avait prédit que nous allions révolutionner l'art dramatique." 
Antoine (1921, p. 9) estava convencido da importância do naturalismo para um novo modo de pensar a cena, como ele pondera: "A batalha, já vencida no romance pelos naturalistas, na pintura pelos impresssionistas, na música pelos wagnerianos, será transportada para o teatro". ${ }^{30}$ E essa nova maneira de pensar incluía a abordagem visual que apareceria em seus textos, como nas Memórias, aqui mencionadas. Refletindo sobre a publicação do crítico Francisque Sarcey (18271899), no folhetim Temps, ele cita impressões sobre Wagner e sobre os Meininger, ${ }^{31}$ cuja menção aparece em muitos comentadores que se seguiram:

Eu não sei nada sobre música, mas me disseram que Wagner tinha, em algumas óperas, coros em múltiplas partes e que cada série de cantores personificava um elemento distinto na multidão, transformando-se em um conjunto perfeito. Por que, no teatro falado, nós não fazemos isso? O Sr. Émile Zola queria a mesma coisa no Germinal e não o fez por que os administradores alegaram limitações de orçamento. Seu objetivo era repetir os grandes grupos, liderados por figurantes. Esse era o procedimento dos Meininger. | Note-se que eu não estou encantado por eles, como se costuma dizer. ${ }^{32}$ (ANTOINE, 1921, p. 94-95, tradução nossa)

É importante observar que Antoine havia passado duas semanas em Bruxelas, acompanhando o trabalho da companhia alemã, e que os comentários de Sarcey se baseiam no espetáculo da mesma tournée que ele acompanhou, também na capital da Bélgica. Depois de manifestar suas críticas à cenografia dos espetáculos dos Meininger, cuja pintura não the parecia alcançar o nível dos cenários franceses, Antoine (1921, p. 95, tradução nossa) fez observações sobre a luz, que originaram inúmeras citações e referências futuras:

\footnotetext{
30 "La bataille, déjà gagnée dans le roman par les naturalistes, dans la peinture par les impressionnistes, dans la musique par les wagnériens, allait se transporter au théâtre."

31 Meininger Hoftheatertruppe, uma companhia de Teatro dirigida e financiada por Georg II (1866-1914), duque de Saxe-Meiningen, e pela sua mulher, a atriz Ellen Franz, começou as atividades em 1866. A companhia dos Meininger foi uma dentre as primeiras que deram destaque à posição do diretor e influenciou outros artistas, pela sua busca por uma montagem teatral que unificasse os diversos elementos do espetáculo.

"Leurs effets de lumière, très réussis, sont le plus souvent réglés avec une naïveté épique. Ainsi, un fort beau rayon de soleil couchant, venant éclairer une très belle tête de vieillard mort dans son fauteuil, passait tout à coup au travers d'un vitrail, sans gradations, au moment précis où le bonhomme venait d'expirer, uniquement pour faire tableau.| Ainsi encore, après une pluie torrentielle extraordinaire, obtenue par des projections électriques, j'ai eu le chagrin de voir l'eau s'arrêter brusquement, sans transition."

32 "Je ne connais rien en musique; mais on m'a dit que Wagner avait, dans certains opéras, des choeurs à multiplex parties et que chaque série de choristes personnifiait un élément distinct de la foule, se fondait dans um ensemble parfait. Pourquoi, dans le théâtre parlé, ne ferions-nous pas ça? M. Émile Zola le voulait pour Germinal et ne l'a pas pu pour des motifs budgétaires que faisaient valoir les directeurs. Son dessein était de faire répéter longtemps les ensembles sous la conduite de comédiens figurants. Vous voyez, c'était le procédé des Meininger. | Notez que je ne suis pas du tout emballé, comme on dit, par eux."
} 
Seus efeitos de luz, muito bem-sucedidos, são, em grande parte, resolvidos com uma ingenuidade épica. Assim, um belo raio de sol que se põe ilumina a graciosa cabeça de um velho morto, em sua cadeira, passando bruscamente através de um vitral, sem gradações, no momento preciso em que o homem expira, unicamente para criar um quadro [uma imagem particular]. | E ainda, depois de uma chuva torrencial, criada por projeções através da eletricidade, tive a tristeza de ver a água parar de repente, sem transição. ${ }^{33}$

Antoine sublinha questões de tempo/ritmo, e a sua aplicação de certos termos - como é o caso da denominação de "efeito" para os movimentos de luz - é bastante compreensível considerando-se aquele momento no qual esses movimentos ainda incorporavam a novidade e a surpresa que os caracterizava como algo fora do comum. Mais de um século depois, desafortunadamente, continuamos encontrando a abordagem que leva muitos comentadores e artistas a desconsiderarem diferenças entre efeito (especial) e movimento de luz, buscando efeitos em qualquer intervenção da luz, impondo à sua contribuição papéis superficiais, vagos. Como se ela estivesse obrigada a apresentar os tais efeitos mirabolantes, infinitamente. Ou seja, cabe repetir: um efeito que envolve a aplicação da luz é, originariamente, mais um entre outros movimentos (de luz) que constituem a visualidade do espetáculo. A natureza do efeito, por sua vez, pode incluir particularidades de tratamento estético-poético, o que sugere cuidados na sua aplicação.

Ainda se referindo à mencionada publicação de Sarcey, Antoine (189o, p. 103-104, tradução nossa) continua:

Nós ainda ficamos diante de ridículas pinturas de fundo, sem ar, sem profundidade, permitindo, com o risco de perturbar a ação, a preparação ruidosa dos quadros seguintes, abrigados por uma coisa vaga, sobre a qual não se tem medo de pintar escadas, a três metros da ribalta, sob uma luz dura, o que não deixa qualquer dúvida sobre [desmascarando] o truque. [...] | Nossos Administradores, para ganhar tempo, ainda pintam móveis sobre os cenários. ${ }^{34}$

33 "Leurs effets de lumière, très réussis, sont le plus souvent réglés avec une naïveté épique. Ainsi, un fort beau rayon de soleil couchant, venant éclairer une très belle tête de vieillard mort dans son fauteuil, passait tout à coup au travers d'un vitrail, sans gradations, au moment précis où le bonhomme venait d'expirer, uniquement pour faire tableau.| Ainsi encore, après une pluie torrentielle extraordinaire, obtenue par des projections électriques, j'ai eu le chagrin de voir l'eau s'arrêter brusquement, sans transition."

34 "Nous en sommes encore à de ridicules toiles de fond, sans air, sans profondeur, qui permettent, au risque de troubler l'action, de préparer bruyamment les tableaux suivants, à l'abri d'une chose vague, sur laquelle on ne 
Aí está uma mostra explícita da sua desaprovação ao tratamento visual do teatro francês, em curso no seu tempo. Ele desejava introduzir elementos que observara em espetáculos de outros países, em busca de credibilidade para o seu trabalho: a iluminação dos cenários (que ele chama "projeções luminosas") assim como as variações na cenografia aplicadas pelos alemães; dos ingleses, os movimentos sutis da cenografia, os objetos em relevo e o aspecto natural. Além disso, na opinião de Antoine, as características dos teatros estavam muito aquém da qualidade indicada para atender às necessidades do novo espetáculo.

Ele clamava pela construção de uma nova sala de espetáculos, não sem antes afirmar que diante da quantidade de teatros em Paris, só se justificaria tal empreendimento se fosse construído o que ele denominou um teatro "modelo". O capítulo que trata desse teatro modelo, na sua publicação Le théâtre libre (1890), deveria ser leitura obrigatória, ainda hoje, para arquitetos envolvidos em projetos de casas de espetáculo. Antoine questionava a salubridade, a segurança, o valor dos ingressos, a acústica e, entre outros pontos, inicia o capítulo abordando a visibilidade. Resumindo a composição de um teatro em três partes principais, orquestra, plateia (de forma circular) e um número variável de balcões, ele emite uma opinião contundente sobre essa disposição dos espectadores: "A forma circular de um teatro é, portanto, ilógica, contrária a uma representação teatral racional". ${ }^{5}$ (ANTOINE, 189o, p. 46, tradução nossa)

Ainda que o adjetivo "racional" possa abrir espaços para críticos de ocasião geralmente rápidos e superficiais que, simploriamente, atacariam as relações com a racionalidade, vale a pena algum esforço e/ou atenção para identificar as demandas de André Antoine, considerando sua contemporaneidade. Ele diz:

O espectador, que nos últimos vinte anos viu seu cotidiano se transformar consideravelmente no que refere ao conforto, quando vai ao teatro, se vê diante de condições absolutamente inferiores àquelas que encontra na sua própria casa, nas ruas, ou em seu trabalho. ${ }^{36}$ (ANTOINE, 1921, p. 48, tradução nossa)

Antoine assume, num certo sentido, uma postura de empresário que procura se alinhar com a história e trazer o público para o seu lado. Nem mesmo a mais

\footnotetext{
craint pas de peindre des escaliers à trois mètres de la rampe, dans une lumière crue, ne laissant aucun doute sur la tricherie. | Nos Directeurs em sont encore, pour gagner du temps, à peindre des meubles sur les décors."

35 "La forme circulaire d'une salle de théâtre est donc illogique, contraire à une représentation rationnelle."

36 "Le spectateur qui, depuis vingt ans, a vu sa vie journalière se transformer considérablement au point de vue du confortable, se retrouve, dès qu'il veut aller au théâtre, dans des conditions absolument inférieures à celles dont il jouit chez lui, ou dans la rue, ou à son travail."
} 
importante casa de espetáculos da época, a Comédie Française, escapou dos erros de arquitetos que repetiam a fórmula reconhecida no teatro italiano, perpetuando os equívocos. Antoine comentou a acústica da Comédie acentuando que para o público acomodado no último balcão os sons eram confusos e abafados. A noção de conforto, no entanto, mostra a amplitude de sua compreensão do teatro, definindo uma busca abrangente por respostas às demandas que uma sala de espetáculos efetivamente nova deveria atender:

Uma tentativa nesse sentido será, portanto, absoluta, completa, satisfatória, se já partir, inexoravelmente, desse princípio: um teatro deve ser construído para o espectador que ocupe a pior localização na plateia. Precisamos pensar no milésimo espectador. E não podemos simplesmente dar-lhe uma cadeira onde ele possa sentar-se, num ponto onde é possível chegar sem quebrar os joelhos, mas é preciso que coloquemos o espetáculo que ele veio assistir, diante dele, e não à sua direita ou à sua esquerda. | Se mantivermos as galerias [os balcões] na forma atual, isto é, se colocarmos o espectador acima da imagem que ele paga para ver, ele não verá, mesmo sentado à sua frente, mais que o piso do palco ou, se ele estiver nos dois balcões superiores, a cabeça e uma distorção dos atores. ${ }^{37}$ (ANTOINE, 1921, p. 48, tradução nossa)

Considerando o espaço erigido para abrigar uma manifestação artística visceralmente entranhada em relações visuais com o seu público, as instalações teatrais encontradas em Paris eram, em sua opinião, equivocadas. Elas sonegavam um importante direito de quem vai ao teatro, qual seja aquele de ver o espetáculo, e se revelavam incompetentes na realização de um dos mais relevantes aspectos do palco chamado "italiano" que, aliás, serviu como apoio generalizado para os críticos, ou seja: emoldurar uma ação que se tornava visível através de uma parede falsa ou inexistente. Afinal, o modelo teatral reproduzido dos italianos, com sua plateia circular, nem sequer "merecia" a crítica que lhe era dirigida, pois oferecia uma visibilidade apenas sofrível na qual a maioria das pessoas acomodadas nas laterais dos balcões tinha diante de si em lugar do espetáculo, literalmente,

37 “Une tentative dans cet ordre d'idées ne sera donc absolue, complète, satisfaisante, qu'en partant tout de suite et inexorablement de ce principe: édifier une salle de théâtre pour le spectateur le plus mal placé de cette salle. C'est ce millième auditeur qui doit nous occuper. Et non seulement nous devons lui donner un fauteuil où il puisse s'asseoir, où il lui soit possible d'arriver sans se briser les rotules, mais il faut que nous placions le spectacle qu'il vient voir, en face de lui, et non à sa droite ou à sa gauche. | Si nous maintenons les galeries dans la forme actuelle, c'est-à-dire si nous plaçons l'auditeur au-dessus du tableau qu'il paie pour voir, il ne pourra, même placé de face, que contempler le plancher du théâtre ou, s'il est aux deux derniers étages, le crâne et le raccourci des acteurs." 
outros espectadores, como afirma Antoine. Tal situação resultava em negligência no que se refere à visibilidade do espetáculo. Ele até disse que em todos os teatros de Paris, naquela época, havia lugares nos últimos balcões de onde não se via nada daquilo que acontecia no palco.

Aí falava também o artista, deixando um ensinamento óbvio, mas nem por isso hoje identificado e praticado. Se emprestarmos algum valor às preocupações de Antoine constataremos que, ainda hoje, teatros famosos nos quais se investiu enorme soma de recursos continuam repetindo essa categoria de erro. Copiados sucessivamente, transformam em regra impropriedades técnicas que acabam por se afirmar como verdade, de tal modo que, questionar parece uma atitude absurda.

Antoine, por outro lado, revelou admiração pelo teatro de Bayreuth (Festspielhaus), inaugurado em 1876, para o festival onde foram montadas as óperas de Wagner, inovando em aspectos importantes quando excluía as galerias de balcões e apresentava uma plateia na forma de "leque", em declive no sentido do palco. Há duas principais indicações para a origem das características particulares desse teatro. Segundo o Oxford companion to the theatre (HARTNOLL, 1957), o projeto aplicado na construção orientada pelo arquiteto da cidade de Bayreuth, foi originalmente concebido por Gottfried Semper (1803-1879) para um teatro em Munique e empregado pela primeira vez por Edward Shepherd (?-1747), em 1733. Parece compreensível a predileção de Antoine pelas características do Bayreuth já que ele compartilhava com Wagner o desejo de uma plateia na qual todos os espectadores tivessem a liberdade de ver, integralmente, o espetáculo.

Essa é uma importante nuança da questão, pois revela diferenças entre o discurso sobre a visualidade e sua efetivação. É também verdade que, observando em detalhe o Festspielhaus podem-se identificar progressos - no que se refere à visibilidade - em comparação com o design italiano que se instalou nas casas de espetáculo desde a renascença, como se pode ver no Teatro Farnese, já mencionado (Figura 35). É possível identificar no Farnese o objeto da crítica de Antoine sobre a impropriedade da acomodação dos espectadores, dispostos em grande parte uns em frente a outros enquanto o espetáculo ocorria no palco, à sua direita ou à esquerda (ainda que, no Farnese - o que parece mais apropriado, do ponto de vista da visibilidade - possa ter ocorrido espetáculos diversos como disputas de cavaleiros e até combates navais, no espaço entre um e outro lado da plateia). Portanto, se forem consideradas as inovações do Bayreuth, os ataques ao teatro italiano deveriam mudar de direção e concentrar forças numa crítica ao teatro alemão ou, melhor, na direção das iniciativas de Wagner, defensor de uma tipologia do espaço teatral que privilegiava a disposição frontal da plateia. 
Por outro lado, comparando hoje as aspirações de Antoine com as características do Bayreuth (Figura 108), determinados aspectos ou detalhes técnicos podem ser observados, sugerindo discussões. De acordo com suas proposições é indispensável que se coloque o espectador, visualmente, diante do espetáculo; no teatro que abrigou a obra de Wagner, no entanto, isso não acontece integralmente. Consultando-se a planta-baixa do Bayreuth (Figura 109) é possível traçar algumas ponderações: à primeira vista parece comprovada a firme relação frontal entre a plateia (1) e o palco (4), intermediados - ou separados - pela orquestra (2) e pela boca de cena (3). A plateia em nível único, cuja planta-baixa lembra a mencionada forma de "leque", deixa, contudo, espaços para questionamentos, precisamente pela localização dos espectadores acomodados nos limites laterais desse leque. Observe-se na Figura 109 que parte do palco é visualmente inacessível aos espectadores localizados em (1a) e (1b) originando, para aqueles sentados nos pontos extremos uma visão muito limitada, representada pelo triângulo isósceles (2a).

Parece óbvio que, para atender ao rigor desejado por Antoine, concentrando a plateia no retângulo (1) da Figura 109, parte substancial dos assentos seria perdida, o que sempre representa um terror para produtores e artistas. Afinal, é compreensível que um investidor ou um artista queira sempre uma plateia com a maior quantidade possível de espectadores; isso representa uma demanda passível de ser entendida e facilmente atendida. No caso do Festspielhaus, poder-se-ia apresentar uma solução, mantendo, e até ampliando o total de espectadores na plateia. Para isso bastaria demolir os elementos 3 e 4, deslocando horizontalmente os limites da boca de cena, ampliando coxias e bastidores, assim como os acessos laterais para o público, entre as linhas tracejadas em azul e a plateia.

Os entraves principais para a realização de tal incremento residiriam em duas limitações: orçamento e reconhecimento da contribuição da visualidade para a práxis cênica. Seria possível também conceber uma edificação como aquela que resultou da parceria entre Adolphe Appia e Emile Jacques-Dalcroze (1865-1960) no projeto do Teatro de Hellerau (Hellerau Festspielhaus) construído em Dresden, na Alemanha, no ano de 1911. Influenciado pelo teatro grego, Appia propôs um espaço - ainda que coberto - totalmente aberto, tanto na dimensão vertical quanto horizontalmente, indicando algo efetivamente novo se forem consideradas as convenções que se impuseram desde o Renascimento. ${ }^{38} \mathrm{O}$ trabalho de Adolphe Appia será abordado adiante, no capítulo final deste livro, "A luz e a cena não realista".

38 De acordo com Brockett (1995, p. 444), Appia contribuiu para o projeto desse que foi o primeiro teatro moderno sem boca de cena e um palco completamente aberto. 
Pode soar como excesso aplicar tal rigor à visualidade da cena. No entanto, o grau de exigência é o mesmo usado em inúmeras instâncias da atividade humana nas quais se domina um contexto e se definem normas. Como quando se revisa um projeto, um artigo, ou outro texto acadêmico, e se aponta uma vírgula posicionada de modo indevido, para atender a regras gramaticais e estilísticas definidas por alguma norma. No caso de um projeto orientado pela excelência da proposição de Antoine, o estudioso seria obrigado a mudar de posição - ou excluir - não apenas uma vírgula, mas, em inúmeros casos, um enorme volume de alvenaria, concreto, ferro, madeira, e assim por diante. Talvez fosse possível analisar os projetos de teatros com o rigor técnico originado na orientação de um consultor especializado em arquitetura teatral acompanhado de um cenógrafo com experiência na definição prioridades visuais. Não se trata de exclusiva aplicação da "sensibilidade" e significa muito mais do que a escolha de materiais sofisticados para o acabamento ou para uma "volumetria" interessante. Afinal, estaria Antoine equivocado quando desejava que em um edifício cujo planejamento e denominação foram originados na capacidade visual do ser humano, um teatro, fosse respeitado o direito à visibilidade?

Assim como outras edificações, um teatro é um espaço cujo uso apresenta particularidades. É indispensável, portanto, o apoio a estudantes de arquitetura interessados em projetos de casas de espetáculo, incluindo na sua orientação crítica a projetos já construídos, identificando equívocos para se evitar que o desconhecimento origine a reprodução dos tantos equívocos. Teatros construídos sem excelência na previsão do seu uso por artistas e técnicos resultam em problemas, graves e complexos. Por outro lado, a enorme carência da comunidade teatral inclui a escassez de espaços para a realização dos seus espetáculos fazendo com que os artistas aceitem edificações cujos projetos deveriam ter sido reprovados na prancheta, ou na tela do monitor, mesmo aqueles desenhados em programas de computador, famosos e caros.

De acordo com os pressupostos definidos pelos seus textos, se fosse possível encontrar um teatro construído por Antoine, apresentando uma plateia com perfeita visibilidade frontal, os comentadores seriam obrigados a mudar ou, ao menos, deveriam deslocar a crítica dirigida ao chamado "palco italiano" para encaminhá-la ao "teatro francês" ou "antoineano". De todo modo, quaisquer que tenham sido os aspectos positivos do projeto de Antoine, eles parecem ter sido sufocados pela sua ligação com o naturalismo, combatido já no seu próprio tempo. Tal ligação parecia fortalecida na dramaturgia e na teoria de sua época, como se pode registrar na citação que se segue, originada num evento ocorrido em 13 de janeiro de 1893: 
"Strindberg, para sua tragédia Senhorita Júlia, que vamos representar, escreveu um longo prefácio repleto de coisas curiosas; pareceu-me necessário imprimir e distribuir aos espectadores."39 (ANTOINE, 1921, p. 286, tradução nossa)

No prefácio, que será abordado a seguir, August Strindberg (1849-1912) deixou importantes elementos para a discussão encaminhada no trabalho em curso, ao tratar das possíveis relações entre a luz e a cenografia no teatro realista.

No programa da montagem de Senhoria Júlia, em 2002, Ewald Hackler diz que o pequeno Théâtre Libre em Paris, fundado em 1887, tornou-se mundialmente famoso pelas montagens de peças naturalistas, em um ato, inspirando-se em Strindberg, que escreveu entre 1888 e 1892 onzes peças do gênero, dentre elas A mais forte e Senhorita Júlia. ${ }^{40}$

\section{A LUZ DA CENA MODERNA COMO VARIAÇÃO DA REALIDADE}

O título acima deriva do mencionado prefácio de Senhorita Júlia, de Strindberg, ambos escritos em 1888. É importante sublinhar: a peça representa uma fase específica na obra de Strindberg, que sempre procurou novas maneiras de responder às suas inquietações de artista. Desde o início da sua carreira, em 1870, ele viu montado seu primeiro texto, I Rom (Em Roma), ainda sob a influência das tradições românticas voltadas para temas históricos, sagas e fantasias.

No prefácio de Senhorita Júlia, ele revelou ligações com a abordagem clássica do teatro e apontou para a caracterização da dramaturgia moderna:

Quando escolhi o tema [tirado de uma história real] que me contaram há alguns anos e que deixou em mim profunda impressão, vi nele o argumento de uma tragédia, pois é trágico, sem dúvida, ver uma pessoa favorecida pela sorte sucumbir e, mais trágico ainda, assistir ao extinguir-se de uma família. (STRINDBERG, 1970, p. 2)

Strindberg deixou margem para críticas políticas ao se referir à posição social da personagem central como se sua posição social resultasse de favorecimento da sorte, em lugar de questionar os aspectos abrangentes da construção de riqueza. Além disso, sua relação com a instituição familiar também pode provocar excla-

39 "Strindberg, pour sa tragédie de Mademoiselle Julie que nous allons jouer, avait écrit une assez longue préface pleine de choses curieuses; il m'a paru utile de la faire imprimer et distribuer à nos spectateurs."

40 Senhorita Júlia estreou com direção de Ewald Hackler, e cenografia de Maurício Pedrosa, em 2002, na Sala 5 do Teatro Martim Gonçalves, Salvador/Bahia. No elenco: Jussilene Santana, Júlia; Agnaldo Lopes, Jean; Lika Ferraro, Cristina; Oswaldo Baraúna Neto, lia as rubricas durante o espetáculo. 
mações. Aqui, entretanto, será destacado um aspecto da declaração: ele afirmou que o tema foi retirado de uma história "real". Tratava-se de um momento do seu teatro no qual Strindberg acentua o vínculo com histórias reais, o que pode sugerir a necessidade de ilusão para convencer o público da verdade na cena. Dessa necessidade derivaram aspectos decisivos para sua estratégia de dramaturgo. Ele elaborou sua Júlia como resultado de um emaranhado de razões entranhadas no contexto social, em meio a densos comprometimentos psicológicos originados no contexto familiar da personagem e, portanto, em sua formação para a qual o ambiente tem importante papel. Strindberg fez tais escolhas, provocado pela sua noção de complexidade das causas que geram a ação humana, buscando a revelação de personagens diferentes dos tipos fixados pelo teatro burguês que, segundo o próprio Strindberg, aparecem até mesmo em Molière.

Numa atitude que lembra Corneille, ele defendeu o monólogo, privilegiando o verossímil em detrimento de regras impostas à conduta teatral. Ficava justificado o caráter irregular dos pensamentos e dos diálogos, pois assim se dá, "na realidade" (STRINDBERG, 1970, p. 10), enfatizando uma curiosidade "quasi-científica":

[...] não nos satisfaz ver que alguma coisa acontece, se não nos mostram como ela acontece. Queremos enxergar os fios, o mecanismo, examinar o fundo duplo, apalpar o aro mágico, para descobrir o ponto de junção, inspecionar as cartas para ver de que modo estão marcadas. (STRINDBERG, 1970, p. 10)

O revolver investigativo requer grande domínio do dramaturgo sobre suas ferramentas e suportes, para prover unidade com assimetria, irregularidade e economia, criando uma convenção sofisticada e eficiente. Strindberg parece se referir à performance de um mágico na qual ele fazia parte daquele público que só se interessa pelo resultado de um truque se lhe for dado conhecimento dos mecanismos que o tornaram possível. O desejo do espectador, revelado por Strindberg, inclui a sensação táctil, que atua como uma metáfora da agudez do seu olhar, um olhar que quase "toca" o ator em cena. Isso exige do artista, portanto, extremo cuidado na elaboração visual do espetáculo.

Revelando interesse pela pintura impressionista, ele escrevia com o olhar já lançado no palco buscando um dispositivo cenográfico que levasse o público a apreender o espaço cênico como uma rigorosa seleção extraída da totalidade do seu próprio ambiente. No teatro naturalista de Strindberg, a cena fazia parte de algo maior, nunca dado integralmente, a realidade. Essa abordagem já seria motivo suficiente para incluir seu trabalho na discussão dos compromissos entre cena e visualidade. No teatro que abrigava a personagem por ele denominada moderna, 
era importante fortalecer os elos entre o verossímil e a ilusão. Chegava o momento de afastar-se da herança romântica que ele mesmo havia compartilhado; urgia a supressão de Deus e da culpa ainda que fossem mantidas as consequências das ações do homem, nele mesmo e nas suas relações sociais que impõem o julgamento e a punição institucional.

Em decorrência dessa abordagem, Strindberg (1970) propôs experimentações que incluíam a exclusão da divisão em atos, aliada à redução da duração de uma peça. Isso resultaria, em sua opinião, na garantia de uma ação ininterrupta e eficiente, capaz de manter a ilusão, sempre seriamente ameaçada pelos intervalos entre um e outro ato. E preveniria que um espetáculo longo cansasse o público, ainda segundo o próprio Strindberg, infelizmente deseducado para assistir uma peça de ato único, com longa duração, ou, como ele mesmo diz: "[...] o tempo de um espetáculo inteiro". (STRINDBERG, 1970, p. 11)

Demonstrando sua perspicácia técnica, Strindberg criticou a má execução dos cenários cuja construção apresentava estruturas de madeira revestidas de tecido e impedindo a movimentação natural dos atores sob o risco de balançar todo o cenário, denunciando sua fragilidade material que resultava no afastamento da "verdade". Ele também condenou o exagero, assim como a aplicação da pintura para sugerir a tridimensionalidade, já criticada por outros. Essa é uma questão importante para o contexto da ilusão buscada por Strindberg (1970, p. 13):

[...] recorri a um cenário único, seja para fazer as personagens fundirem-se com o ambiente, seja para pôr um paradeiro ao hábito do luxo nas montagens. Quando se tem somente um cenário, pode-se exigir que ele seja verossímil. [...] Mesmo que as paredes continuem sendo de pano, é tempo de se acabar com as prateleiras e os utensílios de cozinha nelas pintados. Já há tantas coisas convencionais, no palco, que precisamos aceitar que deveriam nos poupar o esforço de acreditar em panelas pintadas.

Na última parte do prefácio, ele incluiu a luz encaminhando importantes definições para o seu teatro. Quando se considera o lugar comum da compreensão do tratamento visual realista que é atrelado à criação simplista de atmosferas, observamos na proposição de Strindberg uma clara oposição a tal julgamento, privilegiando as funções que a luz deveria cumprir no seu teatro, que ele denominou drama psicológico moderno: "[...] os mais sutis movimentos da alma devem refletir-se no rosto, mais do que em gestos e gritos". (STRINDBERG, 1970, p. 15) Para que a luz apresentasse uma resposta visual para tal premissa, ele pondera: "[...], 
o mais indicado me parece trabalhar com um palco pequeno, utilizando-se uma forte iluminação lateral e com atores renunciando à maquilagem ou usando-a com sobriedade". (STRINDBERG, 1970, p. 15)

Essa limitação da extensão do palco, principalmente no sentido horizontal, tinha como primeiro objetivo garantir a iluminação de ambos os lados do rosto do ator sem o prejuízo causado pela redução de luminosidade no centro de um palco excessivamente largo. A ideia era permitir um razoável grau de visibilidade em toda a extensão da cena e, ainda, possibilitar ângulos de projeção para a luz que interagissem com os volumes do rosto do ator criando uma visualidade capaz de revelar, principalmente, a fisionomia e a expressividade do seu olhar. Nesse sentido, ele desprezava qualquer maquilagem imposta ao rosto como uma máscara limitadora, mesmo aquela cujo objetivo fosse prover beleza.

Para aquele Strindberg que escreveu Senhorita Júlia, ser "natural" no teatro era mais importante do que ser "bonito". Ele também propôs a exclusão das luzes da ribalta, uma vez que sua posição eliminava detalhes do rosto, deformando e projetando sombras sobre a região dos olhos. ${ }^{41}$

A preocupação de Strindberg (1970, p. 15) com as relações visuais entre o público e o seu espetáculo o levaram a solicitar que a orquestra se tornasse invisível, apontando sérias justificativas: "[...] suas luzes incômodas e suas caras voltadas para o público, [...]".42 É possível imaginá-lo indignado ao pensar que durante seu espetáculo, concentrado num espaço cênico reduzido e tratado visualmente para revelar a expressão do rosto das personagens, o público visse as luzes da orquestra e, mais grave, o rosto de cada um dos músicos, numa concorrência absurda com os atores. Importante observar o legado de Wagner, através do Festspielhaus, ao manter a orquestra fora do alcance visual do espectador.

Ele listou ainda outras decisões importantes para o novo teatro: a retirada de camarotes do proscênio nos quais os ocupantes mais se interessavam pelo que comeriam, do que pelo espetáculo em si. A plateia - mantida em completa escuridão durante a representação - deveria ser projetada em aclive desde a primeira

\footnotetext{
41 Muitas décadas mais tarde, já no século XX, Jean Rosenthal (1912-1969) apostaria nas torres laterais, em projetos de luz para a dança, vistos com frequência na sua parceria com Martha Graham (1984-1991). Vale ressaltar a busca pela sistematização, em um desenho de 1948, e avaliar sua função no desenho técnico para a luz aplicada à cena, assim como em qualquer outra área do conhecimento. O desenho apresenta particularidades da área, mas continua sendo a representação técnica de um projeto. Para o(a) lighting designer é possível observar na representação das torres laterais o importante papel que desempenhavam nos espetáculos (Figura 129).

42 É importante lembrar que Richard Wagner colocou a orquestra sob o piso do palco. Não se viam mais os músicos, e, regendo sentado, o maestro só era visto quando ele ficava de pé ou, ocasionalmente, se podia ver-lhe as mãos. É evidente que Strindberg comentava o atraso dos teatros da Suécia, que não acompanhavam essa tendência.
} 
fileira de assentos, para dar total visibilidade à cena, incluindo o piso do palco de dimensões reduzidas, como já foi dito. Ficava registrado, desse modo, o extremo compromisso entre o teatro que busca o natural como índice de verdade e a visualidade.

Strindberg propôs uma convenção muito particular para a luz do seu teatro, propondo a aplicação de fontes laterais, determinando um grau de realidade muito reduzido ou específico, mesmo que se possa encontrar justificativa para o ângulo de incidência nas arandelas. ${ }^{43}$ Parece, nesse caso, que ele não estava interessado em justificativas realistas, sendo a proposição técnica da distribuição lateral das fontes de luz determinada pelo resultado visual que, em sua opinião, favoreceria a expressão do rosto do ator.

O modo como essa visão sobre o teatro se efetivou na sua dramaturgia pode ser observado desde a rubrica de abertura:

A ação ocorre na noite de São João, o festival de meados do verão que sobrevive dos tempos pagãos. | [CENA - Uma grande cozinha. O teto e as paredes são parcialmente cobertos por cortinas e verdes. No lado esquerdo da cena, a parede do fundo se inclina para cima. Nessa parede do fundo, à esquerda, duas prateleiras cheias de panelas, chaleiras de cobre, caçarolas de ferro e panelas de estanho. As prateleiras são acabadas com um extravagante papel recortado. À direita [do meio] uma grande entrada em arco, com portas de vidro através do qual se vê uma fonte com uma estátua do Cupido, arbustos de lilás em flor e álamos altos. No canto esquerdo da cena, um grande fogão, com capa decorada em ramos de bétula. À direita, a mesa de jantar dos empregados, de pinho branco, e algumas cadeiras. Sobre a mesa há um pote japonês cheio de flores de álamo. O chão está repleto de ramos de zimbro.] | Próximo ao fogão, uma geladeira, uma pia e mesa de pratos. Um grande sino antigo pendurado acima da porta, à esquerda da porta de um tubo de comunicação. | [Kristin, de pé em posição de cegonha, cozinha. Ela usa um vestido leve de algodão e um avental. Chega Jean, usando uma farda e carregando uma bota de montaria com esporas, que põe no chão]. ${ }^{44}$ (STRINDBERG, 2009, p. 69, tradução nossa)

\footnotetext{
43 Luminárias fixadas lateralmente às paredes de uma edificação.

44 "The action takes place on Saint John's night, the mid-summer festival surviving from pagan times. [SCENE A large kitchen. The ceiling and walls are partially covered by draperies and greens. The back wall slants upward from left side of scene. On back wall, left, are two shelves filled with copper kettles, iron casseroles and tin pans. The shelves are trimmed with fancy scalloped paper. To right of middle a large arched entrance with glass doors through which one sees a fountain with a statue of Cupid, syringa bushes in bloom and tall poplars. To left corner
} 
A descrição particular do dispositivo cenográfico revela a importância dos detalhes na construção do ambiente, assim como o uso efetivo dos elementos que constituem a cenografia. A definição de tempo e lugar, incluindo estação do ano e hora, determinava o grau de conforto térmico e contribuía para a atitude corporal das personagens. Escrevendo em um momento no qual se consolidava o conceito da quarta-parede, Strindberg explicitou sua compreensão dos limites dessa convenção. Mesmo reconhecendo os obstáculos para que seja alcançado tamanho grau de naturalidade, ele confessou o desejo de ver um ator de costas para o público, durante a representação. Mas, preocupado com a composição visual do ambiente em si, ele questiona o resultado de uma abordagem superficialmente radical da teoria da quarta-parede que dispusesse móveis na frente do palco e de costas para o público. Ele parecia compreender que a instalação de convenções deve estar subordinada à comunicação visual com o espectador.

Além disso, a rubrica que se refere às influências do ambiente sobre o estado de Júlia, combinada com o trecho a seguir, extraído do prefácio, revela-se de grande valia para o estudo de um iluminador:

[...] a atmosfera da noite de São João, a ausência do pai, a sua própria condição física, o seu lidar com os animais, a excitação provocada pela dança, o fascínio do prolongado crepúsculo da noite de verão, a influência afrodisíaca das flores, [...]. (STRINDBERG, 1970, p. 4)

Numa montagem da peça esse pequeno trecho trará indicações inestimáveis para o tratamento visual da cena. Podem-se estabelecer relações provocadoras entre o ambiente - uma cozinha - e a atmosfera, um longo crepúsculo que antecede uma noite quente de verão numa região que apresenta baixíssimas temperaturas no inverno. Tais elementos podem representar valioso material de estudo, não apenas para essa peça, mas para a abordagem dos traços estético-filosóficos da dramaturgia.

Strindberg poderia ter escrito um artigo científico sobre a questão, poderia haver escrito artigos sobre a interação entre os aspectos sociais e os desejos de uma jovem abastada. Tendo escrito uma peça ele provoca a imaginação do seu público, discutindo limites que pareceriam intransponíveis na vida daquela jovem em particular, se a encontrássemos na "regularidade" do seu cotidiano, nos cômodos "nobres" da sua propriedade. E Strindberg foi incisivo:

of scene a large stove with hood decorated with birch branches. To right, servants' dining table of white pine and a few chairs. On the cud of table stands a Japanese jar filled with syringa blossoms. The floor is strewn with juniper branches]. 
Motivei o destino trágico da Senhorita Júlia com uma abundância de circunstâncias: os básicos 'maus' instintos da sua mãe; a educação imprópria recebida do pai; sua própria natureza e a influência que o noivo exerceu sobre sua mente fraca e degenerada; mas também, e mais imediatamente: a festiva atmosfera do Solstício de Verão; a ausência do pai; sua menstruação; sua ligação com os animais; o intoxicante efeito da dança; o crepúsculo de verão; a poderosa influência afrodisíaca das flores; e, finalmente, a oportunidade de tê-los num ambiente fechado, mais a ousadia do homem excitado. ${ }^{45}$ (STRINDBERG apud TÖRNQUIST; STEENE, 2007, p. 64, tradução nossa)

Ele reforçou sua estratégia, demonstrando a decisão de eleger momentos de grave crise na vida da personagem, prenhes dos densos conflitos que alimentam a ação dramática. As personagens são encontradas em um dos limites da casa, sob a influência de um longo crepúsculo, cujos tons laranjas, azuis aquecidos e violetas, pairam sobre o ambiente. Os ângulos de incidência sugerem texturas, formas e cores, definindo a qualidade visual. A atmosfera está impregnada pelo aroma contundente do lilás. A noite de São João é também conhecida como noite da fogueira, enormes fogueiras; a tradição mandava que fossem acesas ao anoitecer, sendo veneradas até o dia seguinte. A disposição em círculo evidenciava traços ritualísticos; as cinzas abençoariam as plantações e todos os seres vivos. Inimigos seriam sacrificados ao fogo e demônios exorcizados.

Disso resultam importantes indagações para o iluminador, capazes de originar provocações para um artista atento. De tais indagações derivam problemas instigantes para o tratamento da cena: por que o autor definiu aquele lugar e aquela hora para a ação da sua peça? Um dramaturgo cuidadoso já revela nessas definições ou escolhas sua compreensão da natureza humana, das relações entre as personagens, deixando sua opinião sobre tais relações. Um iluminador pode revelar seu ponto de vista sobre essas questões no tratamento que propõe para cada montagem. O fogo pode ser eleito como o deflagrador visual de um acontecimento espetacular, um estimulador dos desejos e/ou dilacerador de corpos.

\footnotetext{
45 "I have motivated Miss Julie's tragic fate with an abundance of circumstances: her mother's "bad" basic instincts; her father's improper raising of the girl; her own nature and the influence her fiancé's suggestions had on her weak, degenerate brain; but also, and more immediately: the festive atmosphere of Midsummer Eve; her father's absence; her period; her preoccupation with animals; the intoxicating effect of the dance; the summer twilight; the powerful aphrodisiac influence of the flowers; and finally chance that drives the two together in a secluded room, plus the boldness of the aroused man."
} 
Vale lembrar que mais adiante em sua carreira, Strindberg descaracterizaria a busca particular do naturalismo investindo em instâncias mais voltadas para o que ele encarava como forças interiores da natureza humana, responsáveis pela revelação de uma realidade mais ampla e profunda. Pondere-se que as iniciativas "não realistas" na práxis cênica já estavam sendo encaminhadas por vários artistas, abrindo caminhos para os questionamentos que serão ampliados no século XX. É possível observar que cada modo particular de construir a cena vem incorporando compromissos com a visualidade e, portanto, com a luz. Resta investigar se o pensamento teatral que se estabelece no século XX apresentou o desejo de desconsiderar ou questionar tais compromissos. Para tanto, serão abordadas a seguir iniciativas aqui denominadas "não realistas", abrigando nessa expressão a diversidade de manifestações que pretendem combater a modernidade. Aliás, por vezes, os autores dessas iniciativas parecem demasiadamente atrelados à modernidade ou até, ao realismo, já na própria nomenclatura.

Ainda está por aparecer uma manifestação que efetivamente destrua os compromissos com a arte teatral que ainda resistiu em Strindberg, Ibsen, Tchekhov, Stanislavski, Jorge Andrade, Eugenio Kusnet, entre muitos outros, e apresente uma conceituação que exclua totalmente os elos com a práxis cênica derivada do projeto da Antiguidade grega, denominada teatro por razões já apresentadas aqui, profundamente imersa nas relações visuais com o público. Espera-se ainda testemunhar uma práxis que assuma a postura do radicalmente novo e desconsidere quaisquer referências às convenções teatrais, banindo a percepção visual. Afinal, os gregos investiram numa manifestação de convenções muito particulares que gerou o conceito moderno de "teatro". 